\title{
A Study of Transient Liquid Phase Bonding Using an Ag-Sn3.0Ag0.5Cu Hybrid Solder Paste
}

\author{
Ag-Sn3.0Ag0.5Cu Hybrid Solder Paste를 이용한 천이액상 확산 접합 연구 \\ Jeong-Won Yoon*, ${ }^{*}$, Dong-Hwan Lee*, and Byung-Suk Lee** \\ *Department of Advanced Materials Engineering, Chungbuk National University, Cheongju, 28644, Korea \\ **Welding and Joining R\&D Group, Korea Institute of Industrial Technology (KITECH), \\ Incheon, 21999, Korea
}

†Corresponding author: jwyoon@chungbuk.ac.kr

(Received July 20, 2021; Revised August 2, 2021; Accepted August 6, 2021)

\begin{abstract}
The feasibility of transient liquid phase (TLP) bonding technology for high-temperature endurable power electronics packaging has been evaluated in this study. An $\mathrm{Ag}-\mathrm{Sn} 3.0 \mathrm{Ag} 0.5 \mathrm{Cu}$ hybrid solder paste was fabricated and used as a bonding material. The bonding reactions between chip/substrate and hybrid solder paste and die shear strengths of the TLP-bonded joints were evaluated during conventional soldering and vacuum soldering processes. Compared to the conventional soldering, the vacuum-soldered joints had fewer voids and relatively good metallurgical microstructures. After TLP bonding, $(\mathrm{Cu}, \mathrm{Ni})_{6} \mathrm{Sn}_{5}, \mathrm{Ag}_{3} \mathrm{Sn}$, and $\mathrm{Cu}_{6} \mathrm{Sn}_{5}$ intermetallic compounds formed at the chip interface, in the middle of the joint, and at the bottom interface, respectively. It was confirmed that the vacuum soldering process could create good interfacial uniformity with minimal voids in the Si chip/ceramic substrate joints. The formation of voids during TLP bonding significantly affected the mechanical shear strength of the TLP-bonded joints. The vacuum-soldered joints had high shear strength values of approximately $40 \mathrm{MPa}$. To ensure the high joint strength and long-term reliability of Sn-based TLP-bonded joints, critical void control in the joints is needed.
\end{abstract}

Key Words: Transient liquid phase bonding, $\mathrm{Sn} 3.0 \mathrm{Ag} 0.5 \mathrm{Cu}$ solder, Power electronics, Intermetallics, Shear strength

\section{Introduction}

The 21 st century has witnessed an unprecedented level of interest in new and renewable energy such as eco-friendly vehicles and PV or wind power generation while reducing the use of fossil fuels, driven by changes in the public awareness of global environmental pollution and the recent implementation of carbon neutrality and energy efficiency policies. In particular, in the field of transportation, there has been an explosive surge of interest in electric vehicles (EVs) and hydrogen fuel cell electric vehicles (FCEVs). These eco-friendly vehicles use battery, power conversion systems, and motor systems as key components, and significant growth in relevant industries is expected ${ }^{1)}$. In particular, the power modules in the inverter system, contains power semiconductors, which plays the role of converting the DC current of the battery into AC current for driving the motor. For these power semiconductors, a high level of reliability is required due to the conditions in driving eco-friendly vehicles, such as high operating temperatures and exposure to harsh environments for a long time ${ }^{2)}$.

To date, for bonding of chips and modules of these power semiconductors, conventional soldering methods using high- $\mathrm{Pb}$ solder and $\mathrm{Pb}$-free $\mathrm{Sn}-\mathrm{Ag}-\mathrm{Cu}$ solder alloys have been mainly employed ${ }^{3,4)}$. However, in order to achieve the reliable operational performance of power modules under high temperature over $200{ }^{\circ} \mathrm{C}$ following the upcoming introduction of silicon carbide $(\mathrm{SiC})$ devices, the chip bonding process with Sn-based solder alloys has come to a limitation. In addition, some solder alloys containing $\mathrm{Pb}$, which can be used in high-tem- 
perature environment, still have the environmental problems as obstacles ${ }^{5)}$. For this reason, in recent years, there has been active research on alternative high-temperature endurable bonding methods such as sinter bonding technology using $\mathrm{Ag}$ or $\mathrm{Cu}$ powder and transient liquid phase (TLP) bonding technology with low melting point bonding material ${ }^{6-13)}$. In particular, the TLP bonding method uses a low-melting-point metal material such as Sn and In to form the high-melting-point intermetallic compounds (IMCs) showing stable properties even at high temperatures. Because the method has a relatively low process temperature and pressure as well as excellent durability at high temperatures, it has been actively investigated using combinations of various metals ${ }^{14-18)}$. In this study, as basic research on TLP bonding technology, hybrid solder paste was fabricated with $\mathrm{Ag}$ and $\mathrm{Sn}-3.0 \mathrm{Ag}-0.5 \mathrm{Cu}$ solder alloys, and the changes in the microstructure and mechanical strength in solder joints were examined according to the change of TLP bonding process, and through analysis of the correlations, the future applicability of TLP bonding method was discussed.

\section{Methods}

In this experiment, micro Ag paste (Microbond ASP 295, Heraeus, Singapore) and $\mathrm{Sn}-3.0 \mathrm{Ag}-0.5 \mathrm{Cu}$ solder paste (Senju Metals, Japan) were used for the fabrication of the bonding paste. In the case of $\mathrm{Ag}$ paste, the Ag metal content was approximately $88 \%$, and the average particle size was around $20 \mu \mathrm{m}$. Also, type-5 (average particle size 15-25 um) paste was used for the solder paste. First, a hybrid paste of Ag paste and solder paste with a weight ratio of 1:2 was prepared. For uniform mixing of the two types of pastes, a revolution-rotation mixer was used under a vacuum atmosphere condition. Fig. 1 shows the schematic diagram of the fabricated paste before and after mixing. The substrate used for the power semiconductor chip bonding process was a direct bond copper (DBC) ceramic substrate with a size of $10 \times 10 \times 0.98 \mathrm{~mm}$, in which a sandwich structure with $\mathrm{Cu} / 96 \% \quad \mathrm{Al}_{2} \mathrm{O}_{3} / \mathrm{Cu}$ laminates was used. The thicknesses of the ceramic layer and the copper layer were $380 \mu \mathrm{m}$ and $300 \mu \mathrm{m}$, respectively. The fabricated paste was screen-printed on the DBC substrate by using a 304 stainless steel metal mask with a thickness of $50 \mu \mathrm{m}$. The size of the opening of the mask was $3 \times 3 \mathrm{~mm}$. For the TLP chip bonding process, a $3 \mathrm{~mm} \times 3 \mathrm{~mm}$ Si dummy chip laminated with 0.1 $\mu \mathrm{m}$ Ti $\backslash 0.1 \mu \mathrm{m}$ Al $\backslash 0.2 \mu \mathrm{m}$ Ti $\backslash 1 \mu \mathrm{m}$ Ni $\backslash 0.2 \mu \mathrm{m}$ Ag layer was used. These dummy chips were placed on the printed paste. Fig. 2 shows a schematic diagram of a chip/ paste/DBC substrate sample in the process of paste printing and chip attachment. Next, the TLP bonding process was performed using SMT reflow scope. The peak temperatures used in the bonding process were 245, 260, and $275{ }^{\circ} \mathrm{C}$, respectively, and the bonding process was performed at the peak temperature for approximately 40 seconds. The reflow temperature profile used in this study is shown in Fig. 3. In addition, a vacuum reflow process was performed for comparison with the air reflow process, and the bonding process was performed using a vacuum reflow machine (SRO 70x, ATV Technologie GMBH, Germany). Fig. 4 shows the reflow temperature profile used in the vacuum reflow process. As can be seen in the figure, the vacuum reflow process was performed with a vacuum atmosphere and formic acid, and the peak temperature was $250{ }^{\circ} \mathrm{C}$

In the sample completed with the bonding process, for evaluation of defects such as voids formed in the joints, non-destructive analysis was performed using X-ray equipment (XSCAN-H160-OCT, XAVIS, KOREA). After completing the TLP bonding process using the fab-

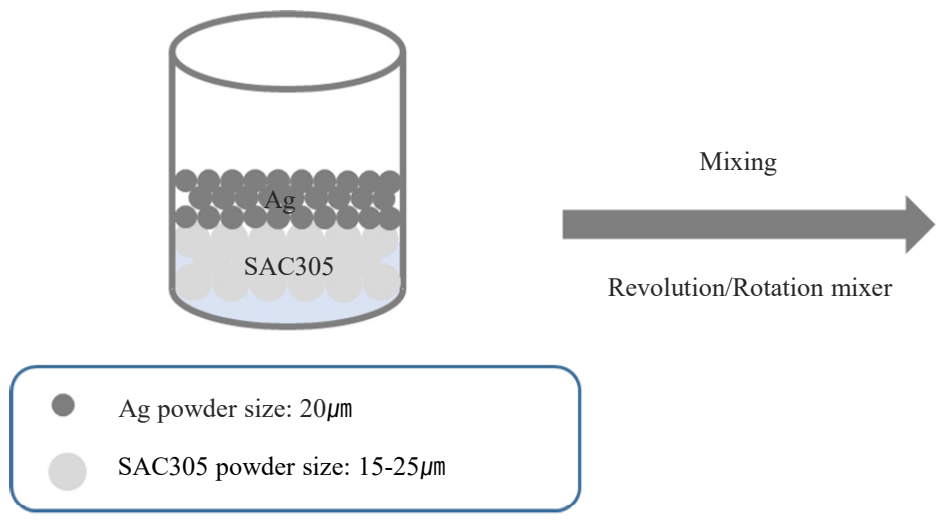

(a)

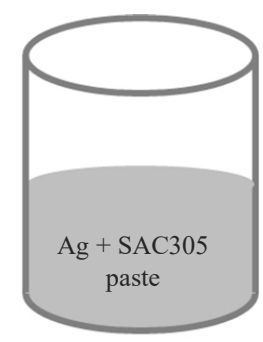

Fig. 1 Schematics of paste fabrication, (a) before and (b) after mixing 


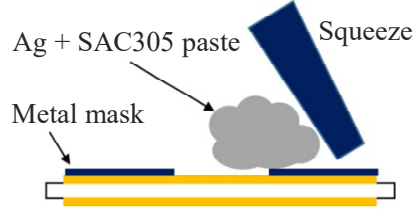

DBC substrate

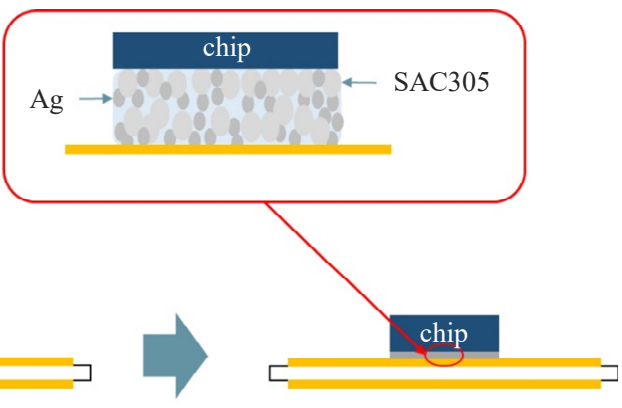

$\mathrm{Ag}+\mathrm{SAC} 305$ paste

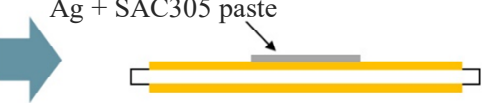

Fig. 2 Schematics of paste printing and chip attachment

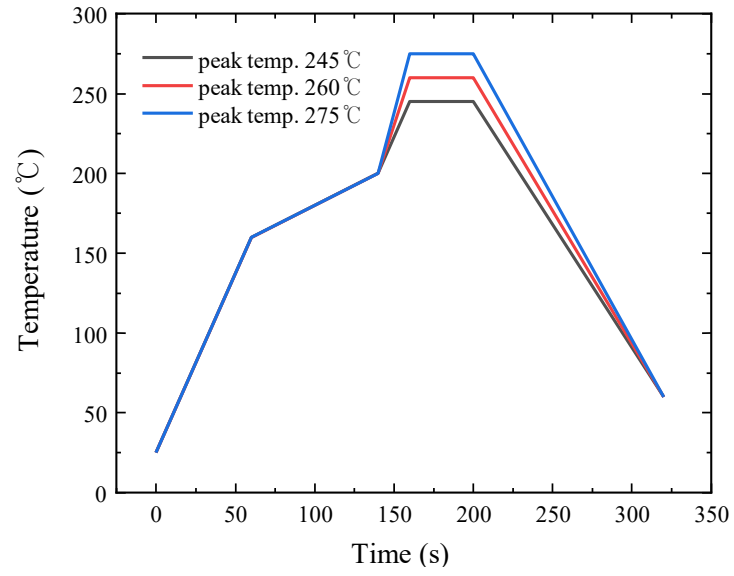

Fig. 3 Temperature profiles used in reflow process

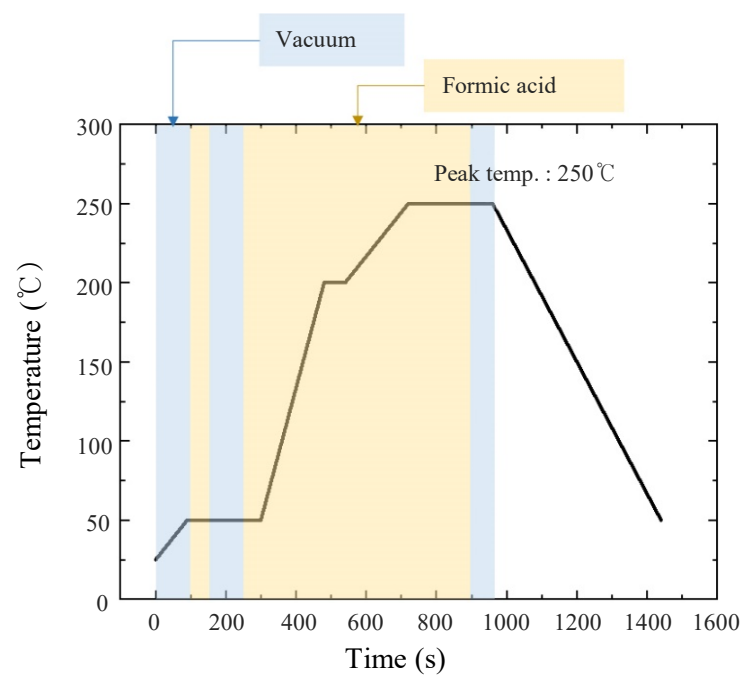

Fig. 4 Temperature profile used in vacuum reflow process

ricated paste, the sample was mounted using epoxy material, and polishing was performed for metallurgical analysis of the cross section. The microstructure and bonding interface of each sample were analyzed using a field emission scanning electron microscope (FE-SEM, INSPECT F, FEI, USA) and an energy dispersive X-ray spectroscope (EDX). To evaluate the mechanical properties of TLP bonding samples, die shear testing was

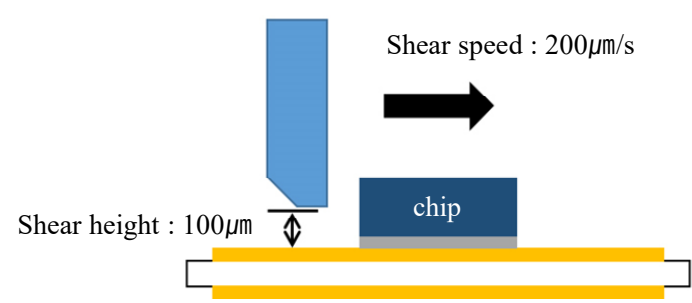

Fig. 5 Schematic of die shear testing

performed using a shear tester (Dage4000, Nordson DAGE, UK). In terms of the shear testing conditions used in this experiment, a shear speed of $200 \mu \mathrm{m} / \mathrm{s}$ and a shear height of $100 \mu \mathrm{m}$ were used (Fig. 5). For evaluation of the die shear strengths, shear testing was performed on a total of 10 joint samples, and the fracture surfaces were analyzed after the shear testing.

\section{Experimental results}

Bonding was performed with different bonding processes to evaluate the bonding characteristics of the fabricated $\mathrm{Ag}-\mathrm{Sn} 3.0 \mathrm{Ag} 0.5 \mathrm{Cu}$ hybrid paste, and Fig. 6 shows the OM images of the bonding sample after the conventional air reflow and vacuum reflow bonding process. As shown in the figure, for the joint sample completed with the conventional air reflow process, the surface of the DBC copper metal layer was oxidized and discolored. On the other hand, in the case of the bonded joint samples from the vacuum reflow process, suppression of the surface oxidation was confirmed. The formic acid $(\mathrm{HCOOH})$ typically used during the vacuum reflow process has a boiling point of approximately $101{ }^{\circ} \mathrm{C}$, and it reduces metal oxides as shown in the following equations. Below is a reaction formula in which two types of copper oxides $\left(\mathrm{Cu}_{2} \mathrm{O}, \mathrm{CuO}\right)$ are reduced by reaction with formic acid.

$$
\begin{aligned}
& \mathrm{Cu}_{2} \mathrm{O}+2 \mathrm{HCOOH} \rightarrow \mathrm{Cu}(\mathrm{COOH})_{2}+\mathrm{Cu}+\mathrm{H}_{2} \mathrm{O} \\
& \mathrm{CuO}+2 \mathrm{HCOOH} \rightarrow \mathrm{Cu}(\mathrm{COOH})_{2}+\mathrm{H}_{2} \mathrm{O} \\
& \mathrm{Cu}(\mathrm{COOH})_{2} \rightarrow \mathrm{Cu}+2 \mathrm{CO}_{2}+\mathrm{H}_{2}
\end{aligned}
$$


(a)

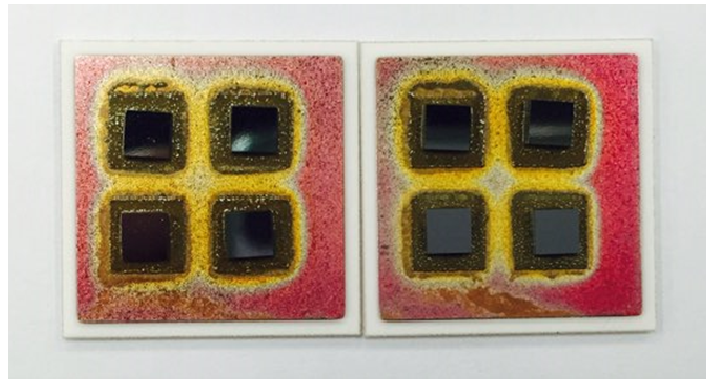

(b)

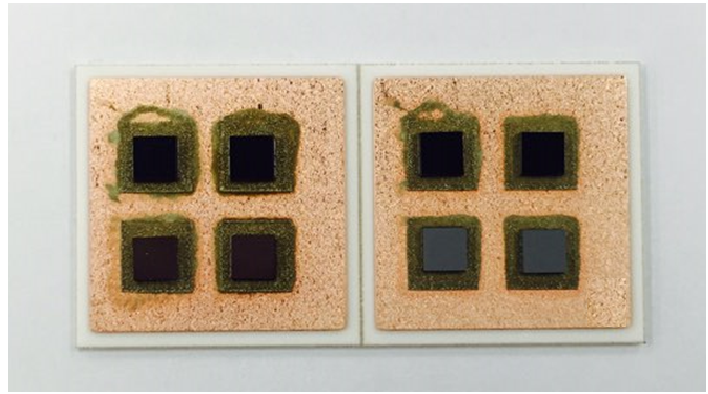

Fig. 6 OM images of (a) air reflowed and (b) vacuum reflowed samples
Fig. 7 shows the non-destructive X-ray analysis images of the bonded joints under various bonding conditions and color images adjusted for these analyzed images using an image software tool. As shown in the figure, no interfacial delamination or non-bonding area was observed at the joint interface, but in the case of the sample bonded by the conventional air reflow process, the presence of a relatively large number of voids was confirmed in the joints regardless of the bonding temperature. On the contrary, in the case of samples bonded by the vacuum reflow process, the formation of quality joints was confirmed without significant defects.

Fig. 8 shows the SEM images of the Si chip/DBC joint interface bonded by the air reflow process at $245{ }^{\circ} \mathrm{C}$ peak temperature. The SEM images of the chip interface, the middle of the joint (bonding layer), and the $\mathrm{DBC}$ joint in the entire joint area are presented by location along with a schematic diagram, respectively. During the bonding reaction, Ag, which is the final metal layer of chip metallization, was all dissolved by reaction with the solder to form a compound phase in-

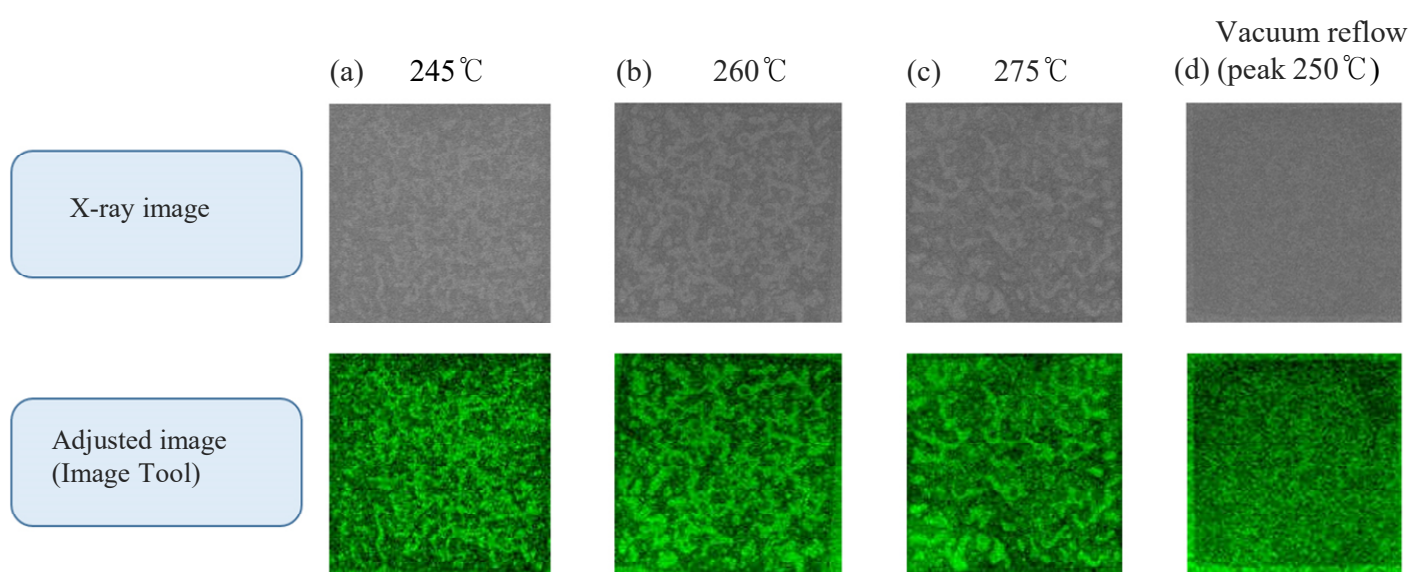

Fig. 7 X-ray images and corresponding adjusted images by image tool software of bonded joints under various conditions

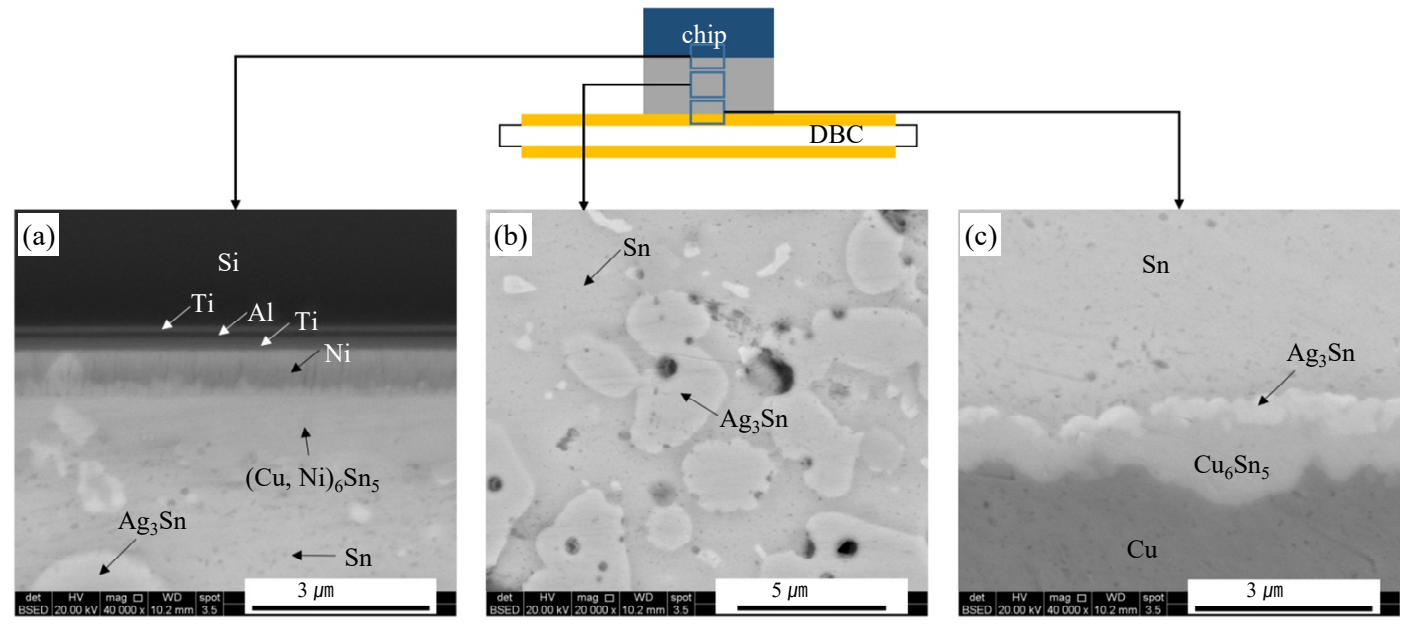

Fig. 8 Cross-sectional SEM images of a Si chip/bonding layer/DBC joint (peak reflow temperature: $245{ }^{\circ} \mathrm{C}$ ) 
side the solder, and the reaction with $\mathrm{Ni}$, the subsequent metal layer, was confirmed. Through the series of reactions, it was confirmed that the $(\mathrm{Cu}, \mathrm{Ni})_{6} \mathrm{Sn}_{5}$ IMC layer containing $\mathrm{Ni}$ was formed at the chip joint interface (Fig. 8(a)). As a result of observing the central part of the joint (bonding layer), it was confirmed that $\mathrm{Ag}_{3} \mathrm{Sn}$ $\mathrm{IMC}$, a compound of $\mathrm{Ag}$ and $\mathrm{Sn}$, was formed and uniformly distributed due to $\mathrm{Ag}$ added in the Sn-3.0Ag$0.5 \mathrm{Cu}$ solder (Fig. 8(b)). As a result of analyzing the lower DBC substrate joint, formation of a $\mathrm{Cu}_{6} \mathrm{Sn}_{5}$ IMC layer at the interface was confirmed due to the reaction between the $\mathrm{Cu}$ layer of the DBC substrate and the solder. Also, due to the added Ag, the additional formation of $\mathrm{Ag}_{3} \mathrm{Sn}$ IMC on the $\mathrm{Cu}_{6} \mathrm{Sn}_{5}$ IMC layer was confirmed (Fig. 8(c)). Fig. 9 and Fig. 10 show SEM images of the Si chip/DBC joints bonded by the air reflow process at peak temperatures of 260 and $275{ }^{\circ} \mathrm{C}$, respectively. Compared with the result of $245^{\circ} \mathrm{C}$ in Fig. 8 , the growth in the size and thickness of the IMC formed at some joint interfaces was observed, but no significant difference was observed, on the whole. Therefore, in this study, it was confirmed that the difference in the reflow peak temperature by $15^{\circ} \mathrm{C}$ did not have a significant impact on the microstructure of the joints.

Fig. 11 shows the SEM images for each location of the $\mathrm{Si}$ chip/DBC joint bonded by the vacuum reflow process. As a result of the composition analysis using EDX, that the types of compounds observed at the chip interface, the middle of the joint (bonding layer) and the DBC joint were confirmed to be identical to the compounds of the samples bonded through the air reflow process. However, overall, the formations of coarse $(\mathrm{Cu}, \mathrm{Ni})_{6} \mathrm{Sn}_{5}, \mathrm{Ag}_{3} \mathrm{Sn}$ and $\mathrm{Cu}_{6} \mathrm{Sn}_{5}$ IMCs were confirmed
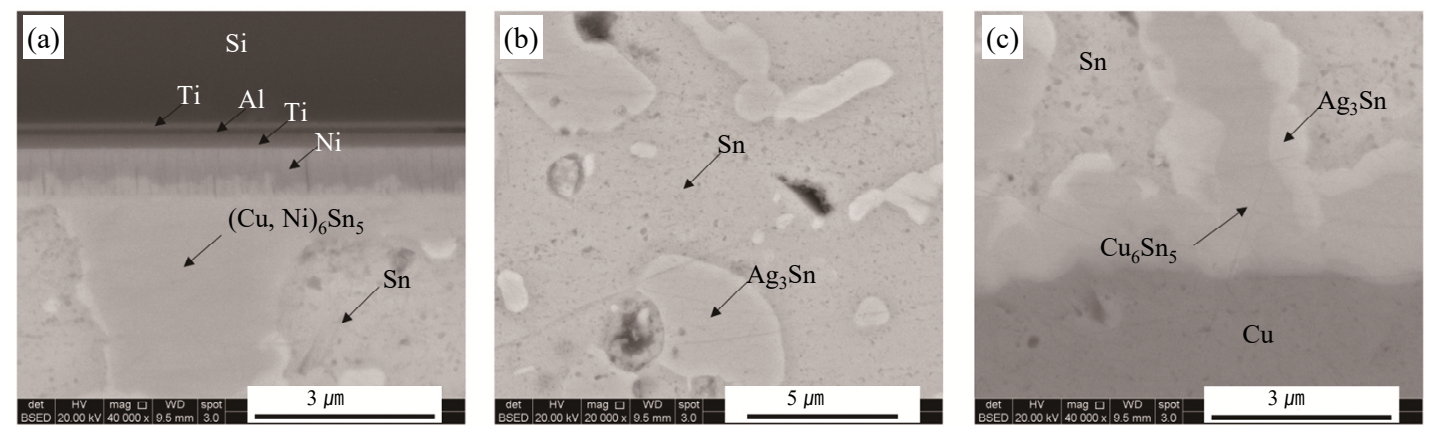

Fig. 9 Cross-sectional SEM images of a Si chip/bonding layer/DBC joint (peak reflow temperature: $260{ }^{\circ} \mathrm{C}$ )
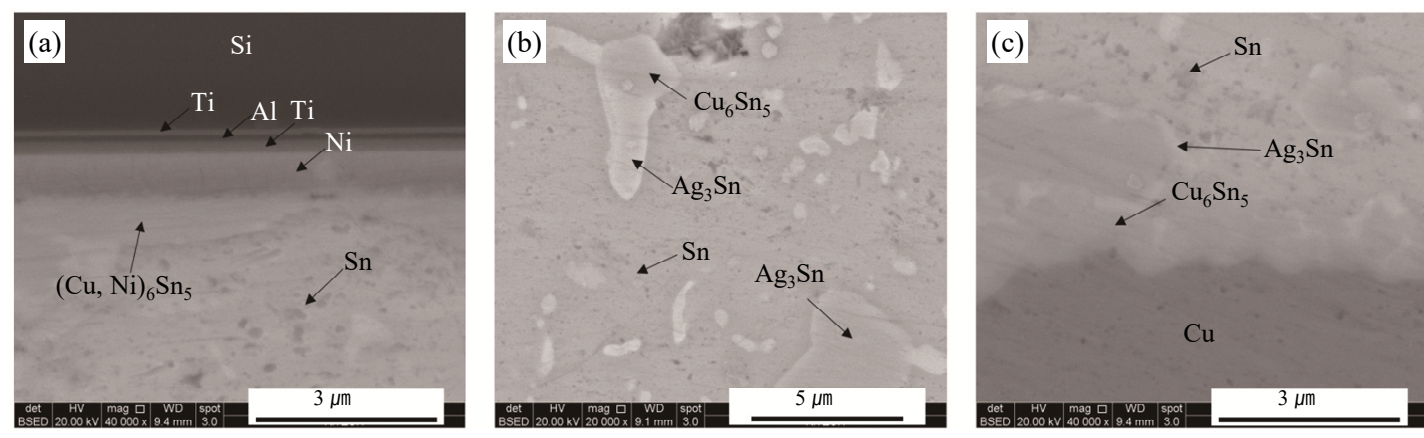

Fig. 10 Cross-sectional SEM images of a Si chip/bonding layer/DBC joint (peak reflow temperature: $275{ }^{\circ} \mathrm{C}$ )
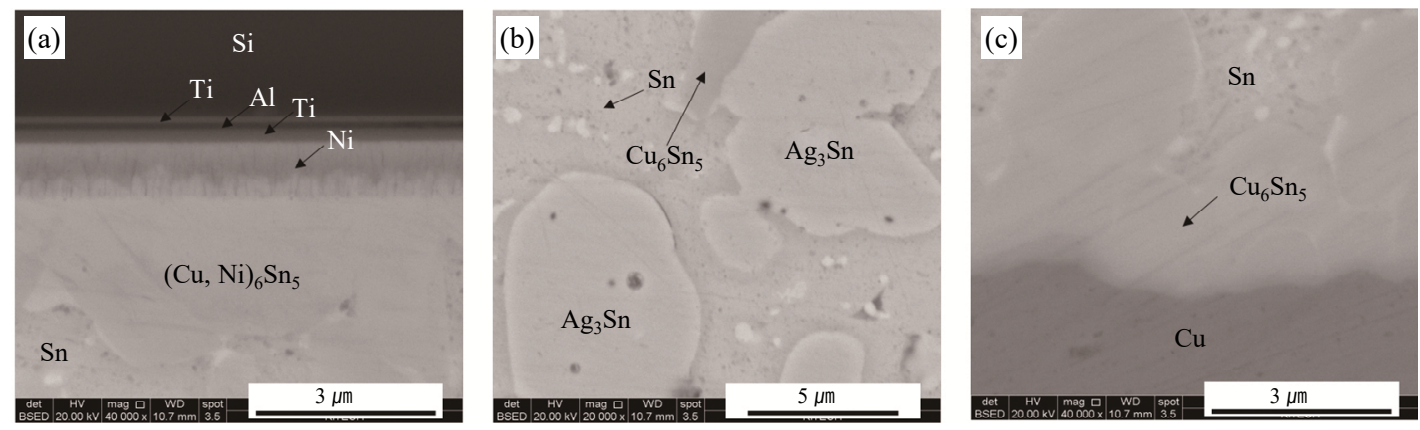

Fig. 11 Cross-sectional SEM images of a Si chip/bonding layer/DBC joint reflowed under a vacuum condition 


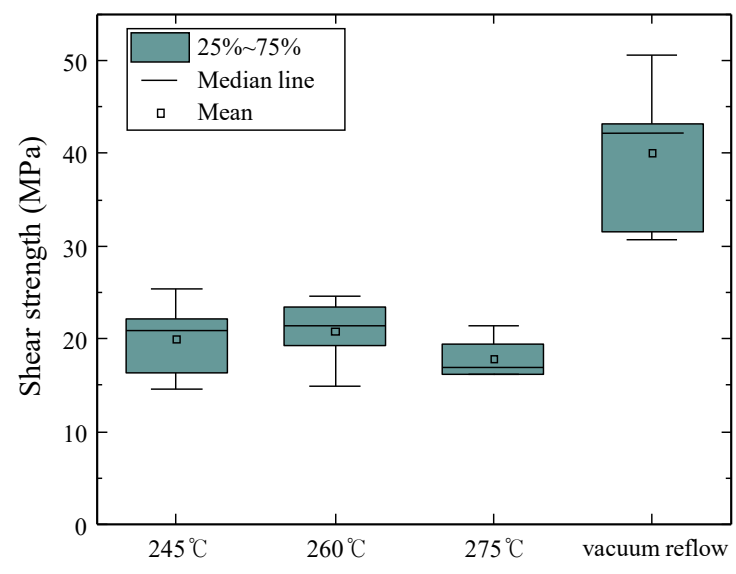

Fig. 12 Variation of die shear strength with reflow conditions

in the joints and bonding layer, respectively.

For evaluation of the effect of bonding process parameters on the mechanical strength of joints bonded through conventional reflow and vacuum reflow processes, die shear testing was performed, and the results are presented in Fig. 12. The shear test results confirmed that the sample bonded by the air reflow process had a shear strength of approximately $20 \mathrm{MPa}$ regardless of the change in the peak temperature. On the other hand, in the case of joints bonded by the vacuum reflow process, the bonding strength was approximately twice that of the air reflow process with an average shear strength value of approximately $40 \mathrm{MPa}$.

To investigate the cause of the significant difference in die shear strength testing result, the fracture surfaces were analyzed after shear testing, and the results are presented in Fig. 13. In the case of the sample bonded by the air reflow process (Fig. 13(a)-(c)), after shear testing, fracture mainly occurred at the chip interface, and the presence of many voids was confirmed on the fracture surface. On the other hand, in the case of joint samples bonded through the vacuum reflow process (Fig. 13(d)), fracture at the chip interface was also confirmed after shear testing, as in the case of the conventional reflow process, but the no significant presence of voids on the fracture surface was confirmed. Considering these results, it was confirmed that the amount and size of voids in the joints created after the different reflow bonding processes used in this study had a significant effect on joint strength. The result of this difference in shear strength (Fig. 12) was consistent with the observation result for the voids in the joints (Fig. 7) according to the difference in the bonding process described above and a schematic diagram outlining these results is presented in Fig. 14. Although the conditions such as process temperature and holding time used in this study are not exactly the same between the air reflow and vacuum reflow processes, in general, as can be seen in Fig. 4, in the vacuum reflow process, the vacuum and formic acid are alternately applied 2-3 times at the initial stage, and thus the oxides formed on the samples are reduced and removed and there is also a process of increasing the degree of vacuum. In addition, even when the process is maintained at the peak temperature, the degree of vacuum is increased again to remarkably reduce the voids present in the molten solder and joints. For this reason, compared to the conventional air reflow process, the vacuum reflow process takes a rather long time. On the other hand, in the air
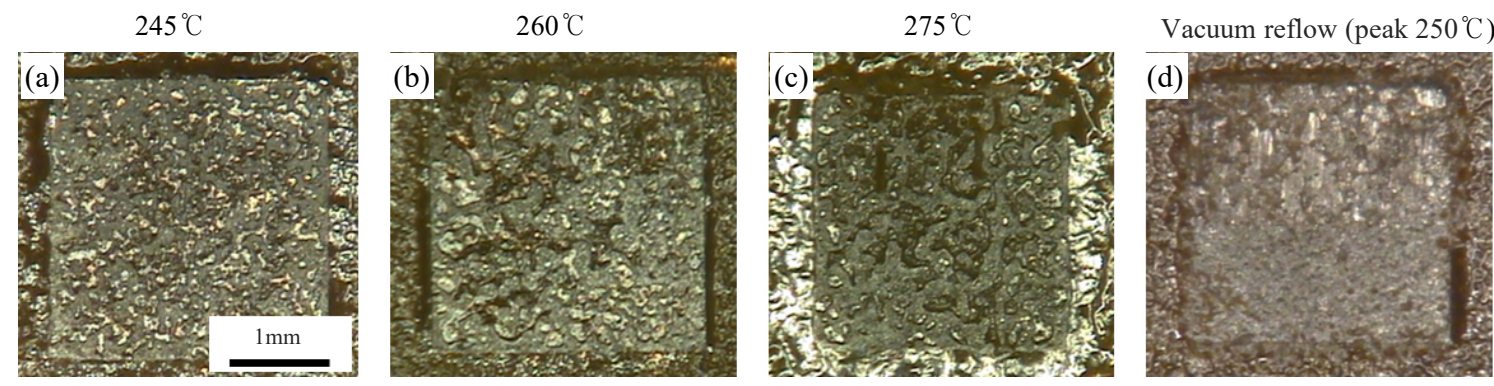

Fig. 13 Fracture surfaces of joints bonded under various conditions
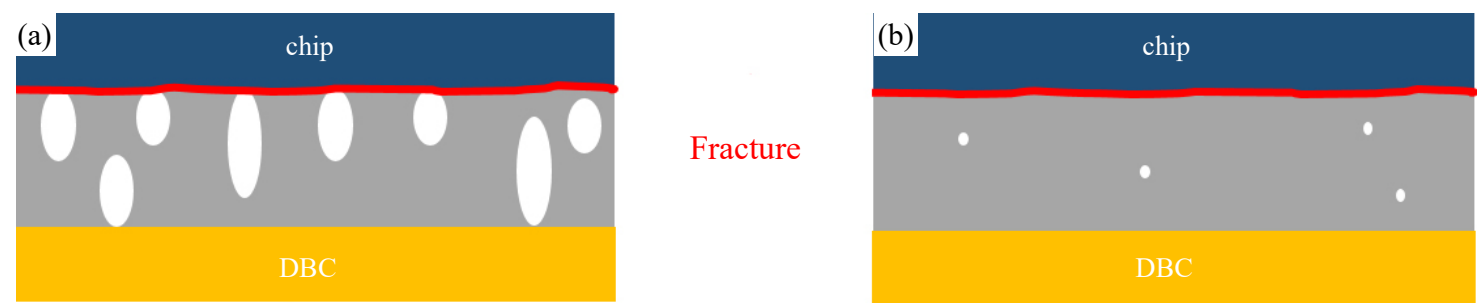

Fig. 14 Schematics of fracture sites after shear testing, (a) air reflow sample and (b) vacuum reflow sample 
reflow process, the voids present in the joint are not spontaneously released during the metallurgical reaction of the molten solder alloys between the chip and the substrate metal. In addition, since a typical size of the power semiconductor chips has an area of several millimeters to approximately 10 millimeters in width and length, the natural removal of voids in the molten solder becomes more difficult. In addition, the action of formic acid used in the vacuum reflow process reduces the oxides present in the sample as described above, and the combination of the action of formic acid and the vacuum atmosphere served to significantly reduce voids in the joints. According to the results of a previous study, in the case of Cu-Sn TLP bonding joint, high shear strength of approximately $50 \mathrm{MPa}$ was obtained by minimizing joint voids and inducing the reaction of $\mathrm{Cu}_{3} \mathrm{Sn}$ compound formation ${ }^{9)}$. Also, as a result of shear testing, shear failure along the chip interface was reported. With the Sn-based TLP bonding, further expansion of its application is expected in electric vehicles and high-temperature-endurable electronic components and modules after undergoing sufficient tests on the reliability due to its advantages as a low-cost, high-temperature-endurable bonding material. Therefore, in this study, basic research on Sn-based TLP bonding was performed to evaluate metallurgical and mechanical properties in the joints according to reflow process parameters for the application as a high-temperatureendurable bonding material. When the TLP bonding process is performed using Sn-based low-melting point metals and alloys, a vacuum reflow process is recommended to ensure joint strength and long-term reliability, and more tightened control of joint voids is imperative. In the future, more in-depth and detailed further studies are needed.

\section{Conclusion}

In this study, as basic research to examine the applicability of TLP bonding in power semiconductor modules endurable in a high-temperature environment, a hybrid solder paste using silver (Ag) and $\mathrm{Sn}-3.0 \mathrm{Ag}-0.5 \mathrm{Cu}$ solder materials was fabricated, and evaluation of changes in microstructure and mechanical strength was performed according to the application of different types of TLP bonding processes, and the following conclusions were derived.

1) In the case of joint samples bonded by the vacuum reflow process, formic acid played a role of metal oxides reduction, and considerable suppression of the surface oxidation of the substrate was confirmed. As a result of non-destructive X-ray analysis of the joints, the presence of many voids in the joints was confirmed in the case of the sample bonded by the air reflow process, but with the vacuum reflowed sample, the formation of a relatively good interfacial uniformity without voids was confirmed.

2) The analysis of the cross-sections of the joints confirmed that $(\mathrm{Cu}, \mathrm{Ni})_{6} \mathrm{Sn}_{5}, \mathrm{Ag}_{3} \mathrm{Sn}$ and $\mathrm{Cu}_{6} \mathrm{Sn}_{5}$ IMCs were formed at the chip interface, middle of the joint and DBC interface at the bottom, respectively, regardless of process parameters.

3) As a result of evaluating the mechanical strength of the joints through die shear testing, in the case of joints bonded by the vacuum reflow process, the average shear strength value was approximately $40 \mathrm{MPa}$, and this value was approximately 2 times higher than that of the air reflow process. It was confirmed that the amount and size of voids created inside the joint after the bonding process had a significant impact on the joint strength.

4) In the future, when the TLP bonding process is performed using Sn-based low-melting point metals and alloys, more stringent control of joint voids under vacuum reflow atmosphere is required to ensure high joint strength and long-term reliability, and in this regard, further systematic optimization study is thought to be necessary.

\section{Acknowledgments}

This research was partly supported by the research grant of the Chungbuk National University in 2020 and Korea Institute for Advancement of Technology(KIAT) grant funded by the Korea Government(MOTIE) (P0008458, The Competency Development Program for Industry Specialist).

ORCID: Jeong-Won Yoon: http://orcid.org/0000-0001-8708-542X ORCID: Dong-Hwan Lee: https://orcid.org/0000-0003-1694-0198

\section{References}

1. A. Matallana, E. Ibarra, I. López, J. Andreu, J.I. Garate, X. Jordà, and J. Rebollo, Power module electronics in $\mathrm{HEV} / \mathrm{EV}$ applications: New trends in wide-bandgap semiconductor technologies and design aspects, Renew. Sust. Energ. Rev. 113 (2019) 109264. https://doi.org/10.1016/j.rser.2019.109264

2. J. W. Yoon, J. H. Bang, Y. H. Ko, S. Yoo, J. K. Kim, and C. W. Lee, Power module packaging technology with extended reliability for electric vehicle applications, $J$. Microelectron. Packag. Soc. 21 (4) (2014) 1-13. http://dx.doi.org/10.6117/kmeps.2014.21.4.001

3. F. Dugal and M. Ciappa, Study of thermal cycling and temperature aging on $\mathrm{PbSnAg}$ die attach solder joints for high power modules, Microelectron. Reliab. 54 
(2014) 1856-1861.

http://dx.doi.org/10.1016/j.microrel.2014.08.001

4. B. S. Lee, Y. H. Ko, J. H. Bang, C. W. Lee, S. Yoo, J. K. $\mathrm{Kim}$, and J. W. Yoon, Interfacial reactions and mechanical strength of $\mathrm{Sn}-3.0 \mathrm{Ag}-0.5 \mathrm{Cu} / \mathrm{Ni} / \mathrm{Cu}$ and $\mathrm{Au}-20 \mathrm{Sn} / \mathrm{Ni} / \mathrm{Cu}$ solder joints for power electronics applications, Microelectron. Reliab. 71 (2017) 119-125.

https://doi.org/10.1016/j.microrel.2017.03.011

5. J. Son, M. Kim, D. Y. Yu, Y. H. Ko, J. W. Yoon, C. W. Lee, Y. B. Park, and J. Bang, Thermal aging characteristics of Sn-xSb solder for automotive power module, $J$. Weld. Join. 35 (5) (2017) 38-47.

https://doi.org/10.5781/JWJ.2017.35.5.6

6. B. S. Lee, J. H. Back, and J. W. Yoon, Effect of sintering conditions on microstructure and mechanical strength of $\mathrm{Cu}$ micro-particle sintered joints for high-power semiconductor module applications, J. Weld. Join. 37 (2) (2019) 26-34.

https://doi.org/10.5781/JWJ.2019.37.2.5

7. Y. H. Byun, C. M. Jeong, J. W. Yoon, C. H. Kim, C. S. Kim, B. W. Lee, S. W. Booh, and U. I. Chung, A novel and simple fabrication technology for high power module with enhanced thermal performance, Proc. 8th IEEE Vehicle Power and Propulsion Conference (VPPC) (2012) 1070-1073.

https://doi.org/10.1109/VPPC.2012.6422503

8. J. F. Li, P. A. Agyakwa, and C. M. Johnson, Interfacial reaction in $\mathrm{Cu} / \mathrm{Sn} / \mathrm{Cu}$ system during the transient liquid phase soldering process, Acta Mater. 59 (2011) 1198-1211. https://doi.org/10.1016/j.actamat.2010.10.053

9. B. S. Lee and J. W. Yoon, Cu-Sn intermetallic compound joints for high-temperature power electronics applications, J. Electron. Mater. 47 (2018) 430-435. https://doi.org/10.1007/s11664-017-5792-2

10. J. W. Yoon and S. E. Jeong, Transient liquid phase sinter bonding with Tin-Nickel micro-sized powders for EV power module applications, J. Microelectron. Packag. Soc. 28 (2) (2021) 71-79.

https://doi.org/10.6117/kmeps.2021.28.2.071
11. B. S. Lee and J. W. Yoon, Die-attach for power devices using the Ag sintering process: Interfacial microstructure and mechanical strength, Met. Mater. Int. 23 (2017) 958-963. https://doi.org/10.1007/s12540-017-6908-1

12. J. W. Yoon and J. H. Back, Effect of sintering conditions on the mechanical strength of $\mathrm{Cu}$-sintered joints for high-power applications, Materials. 11 (2018) 2105. https://doi.org/10.3390/ma11112105

13. K. S. Siow, Mechanical properties of nano-silver joints as die attach materials, J. Alloys Compd. 514 (2012) 6-19. https://doi.org/10.1016/j.jallcom.2011.10.092

14. J. W. Yoon, S. Bae, B. S. Lee, and S. B. Jung, Bonding of power device to ceramic substrate using Sn-coated $\mathrm{Cu}$ micro paste for high-temperature applications, Appl. Surf. Sci. 515 (2020) 146060. https://doi.org/10.1016/j.apsusc.2020.146060

15. J. Liu, K. Wang, F. Yu, C. Hang, X. Fu, H. Chen, and M. Li, A paste based on $\mathrm{Cu} @ \mathrm{Sn} @$ Ag particles for die attachment under ambient atmosphere in power device packaging, J. Mater. Sci. Mater. Electron. 31 (2020) 1808-1816. https://doi.org/10.1007/s10854-019-02697-9

16. L. Sun, Y. Zhang, L. Zhang, and C.P. Chen, Reliability and strength of $\mathrm{Cu}-\mathrm{Sn} 0.5 \mathrm{CuZnAl-Cu}$ TLP bonded joints during thermal cycling, J. Mater. Sci. Mater. Electron. 32 (2021) 19264-19274. https://doi.org/10.1007/s10854-021-06446-9

17. S. E. Jeong, S. B. Jung, and J. W. Yoon, Fast formation of Ni-Sn intermetallic joints using Ni-Sn paste for high-temperature bonding applications, J. Mater. Sci. Mater. Electron. 31 (2020) 15048. https://doi.org/10.1007/s10854-020-04068-1

18. M. Fujino, H. Narusawa, Y. Kuramochi, E. Higurashi, and T. Suga, Transient liquid-phase sintering using silver and tin powder mixture for die bonding, Japan J. Appl. Phys. 55 (2016) 04EC14. https://doi.org/10.7567/JJAP.55.04EC14 


\title{
$\mathrm{Ag}-\mathrm{Sn} 3.0 \mathrm{Ag} 0.5 \mathrm{Cu}$ Hybrid Solder Paste를 이용한 천이액상 확산 접합 연구
}

\section{A Study of Transient Liquid Phase Bonding Using an Ag-Sn3.0Ag0.5Cu Hybrid Solder Paste}

\author{
윤 정 원*이 동 환 \\ *충북대학교 신소재공학과 \\ **한국생산기술연구원 용접접합그룹
}

\section{1. 서 론}

21세기 이후 지구 환경오염에 대한 인식 변화와 최 근의 탄소 중립 및 에너지 효율화 정책 등으로 화석 연 료의 사용을 줄이며 친환경 자동차 및 태양광/풍력 발 전 등과 같은 신재생에너지에 대한 관심이 크게 증가하 고 있다. 특히, 수송기기 분야에 있어서는 전기 자동차 $(\mathrm{EV})$ 및 수소연료전지 자동차 $(\mathrm{FCEV})$ 에 대한 관심 이 폭발적으로 늘어나고 있는 추세이다. 이러한 친환경 자동차는 배터리 (Battery), 전력변환 시스템 (Power Conversion System) 및 모터 시스템 (Motor System) 이 핵심 구성 요소로 이루어져 있으며, 향후 관련 산업 의 큰 성장이 예상된다 ${ }^{1)}$. 특히, 배터리의 직류 전류를 모터 구동을 위한 교류 전류로 변환시키는 역할을 하는 인버터 시스템 내의 전력 모듈 (Power module)은 전 력반도체를 포함하고 있으며, 친환경 자동차의 구동 시 사용 온도가 높고 장시간 가혹한 환경하에서 작동하기 때문에 높은 신뢰성이 요구된다2).

지금까지 이러한 전력반도체 칩 및 모듈의 접합에는 High $-\mathrm{Pb}$ 솔더 및 $\mathrm{Pb}$ 성분이 없는 무연 $\mathrm{Sn}-\mathrm{Ag}-\mathrm{Cu}$ 솔더 합금을 이용한 전통적인 솔더링 (Soldering) 방 법이 주로 사용되어 왔다 ${ }^{3,4)}$. 하지만, 향후 전개될 실 리콘 카바이드 $(\mathrm{SiC})$ 소자 채용 등에 따른 $200^{\circ} \mathrm{C}$ 이 상의 고온 환경하에서 안정적인 전력 모듈의 동작을 위 해서는 $\mathrm{Sn}$ 기반의 솔더 접합 소재를 이용한 칩 접합 공정은 한계에 다다르게 되었으며, 그나마 고온에서 사 용 가능한 일부 $\mathrm{Pb}$ 함유 솔더 합금은 여전히 환경적인 이슈가 남아 있는 상황이다 ${ }^{5}$. 따라서, 최근에는 $\mathrm{Ag}$ 혹은 $\mathrm{Cu}$ 분말을 이용한 소결 접합 기술인 신터링 (Sintering) 접합 기술과 저융점 접합 소재를 이용한 천이액상 확산 접합 (Transient Liquid Phase (TLP) Bonding) 기술 등 다양한 고온 대응 대체 접합법에 대한 연구가
전세계적으로 활발하게 수행되고 있다 ${ }^{6-13)}$. 특히, TLP 접합법은 $\mathrm{Sn}$ 및 $\mathrm{In}$ 과 같은 저융점 금속 소재를 이용하 여 고온에서도 안정한 특성을 보이는 고융점의 금속간 화합물 (Intermetallic Compound, IMC)을 형성시 키는 방법으로, 상대적으로 낮은 공정 온도 및 압력, 고온에서 우수한 내구 특성을 가지고 있기 때문에 다양 한 금속 간의 조합을 이용하여 활발히 연구되고 있는 추세이다 ${ }^{14-18)}$. 본 연구에서는 그에 대한 기초 연구로서 은 $(\mathrm{Ag})$ 과 $\mathrm{Sn}-3.0 \mathrm{Ag}-0.5 \mathrm{Cu}$ 솔더 접합 소재를 이용한 하이브리드 솔더 페이스트 (Hybrid Solder Paste)를 제작한 후, TLP 접합 공정 변화에 따른 접합부 미세구 조의 변화 및 접합부 기계적 강도 변화를 관찰하였으 며, 그 상관관계 분석을 통해 향후 TLP 접합의 적용 가능성에 대하여 고찰하였다.

\section{2. 실험 방법}

본 실험에서는 접합용 페이스트 제작을 위해 micro $\mathrm{Ag}$ 페이스트 (Microbond ASP 295, Heraeus, Singapore) 와 $\mathrm{Sn}-3.0 \mathrm{Ag}-0.5 \mathrm{Cu}$ 솔더 페이스트 (Senju Metals, Japan)가 사용되었다. $\mathrm{Ag}$ 페이스트의 경우 $\mathrm{Ag}$ 금속 함량은 약 $88 \%$ 이었으며, 평균 입자 사이즈는 약 $20 \mu \mathrm{m}$ 였다. 또한, 솔더 페이스트의 경우 type-5 (평균 입자 사이즈 15-25um) 소재가 사용되었다. 먼저, 중량비 $1: 2$ 의 비율을 가지는 $\mathrm{Ag}$ 페이스트와 솔더 페이스트의 혼합 페이스트가 제조되었다. 이들 페이스트의 균일한 혼합을 위해서 진공 분위기 하에서 공자전 믹서를 이용 하여 제조되었다. 믹싱 전과 후에 제조된 페이스트의 모식도를 Fig. 1에 나타내었다. 전력반도체 칩 접합 공정을 위해 사용된 기판은 $10 \times 10 \times 0.98 \mathrm{~mm}$ 크 기의 $\mathrm{DBC}$ (direct bond copper) 세라믹 기판으로, $\mathrm{Cu} / 96 \% \mathrm{Al}_{2} \mathrm{O}_{3} / \mathrm{Cu}$ 가 적층 접합된 sandwich 구조의 기판이 사용되었다. 세라믹 층과 구리 층의 두께는 각 

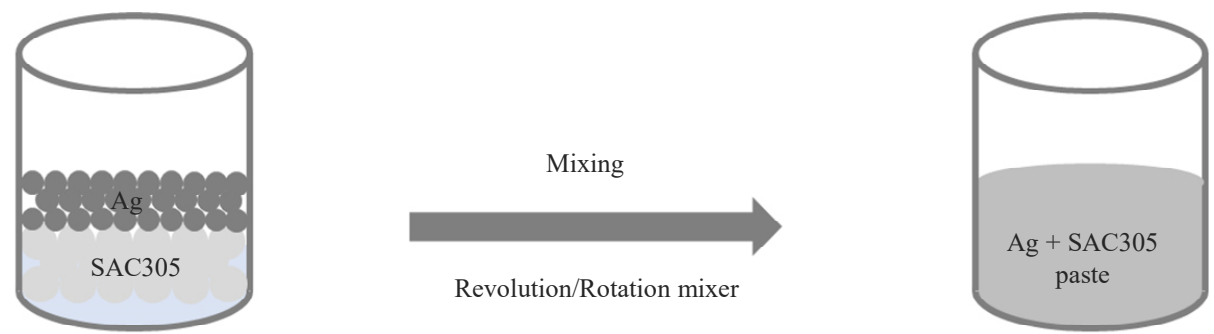

Ag powder size: $20 \mu \mathrm{m}$

SAC305 powder size: $15-25 \mu \mathrm{m}$

(a)

(b)

Fig. 1 Schematics of paste fabrication, (a) before and (b) after mixing

각 $380 \mu \mathrm{m}$ 와 $300 \mu \mathrm{m}$ 였다. $50 \mu \mathrm{m}$ 두께의 304 스테인 리스 스틸 메탈 마스크 (Mask)를 이용하여 제조된 페 이스트를 $\mathrm{DBC}$ 기판 상에 스크린 프린팅 (screenprinting)하였다. 이때 사용된 마스크의 opening 사 이즈는 $3 \times 3 \mathrm{~mm}$ 였다. TLP 칩 접합 공정 수행을 위 해서, $0.1 \mu \mathrm{m} \mathrm{Ti} \backslash 0.1 \mu \mathrm{m}$ Al $\backslash 0.2 \mu \mathrm{m}$ Ti $\backslash 1 \mu \mathrm{m} \mathrm{Ni} \backslash$ $0.2 \mu \mathrm{m} \mathrm{Ag}$ 층이 증착된 $3 \mathrm{~mm} \times 3 \mathrm{~mm} \mathrm{Si} \mathrm{dummy}$ chip이 사용되었다. 프린팅된 페이스트 위에 이들 dummy chip이 올려졌다. Fig. 2는 페이스트 프린팅과 칩 접 합 공정에 있어서 chip/페이스트/DBC 기판 시편의 모 식도를 보여준다. 그 다음으로 TLP 접합 공정이 일반 리플로우 장비 (SMT scope)를 이용하여 수행되었다. 사용된 접합 최고 온도는 각각 $245,260,275{ }^{\circ} \mathrm{C}$ 였으 며, 최고 온도에서 약 40초 동안 접합 공정이 수행되 었다. 본 연구에 사용된 리플로우 온도 프로파일을 Fig. 3에 나타내었다. 또한, 일반 리플로우 공정과의 비교를 위해 진공 리플로우 공정이 수행되었으며, 진공 리플로우 공정 장비 (vacuum reflow machine SRO 70x, ATV Technologie GMBH, Germany)를 이용 하여 접합 공정이 수행되었다. Fig. 4는 진공 리플로 우 공정에 사용된 리플로우 온도 프로파일을 보여준다.

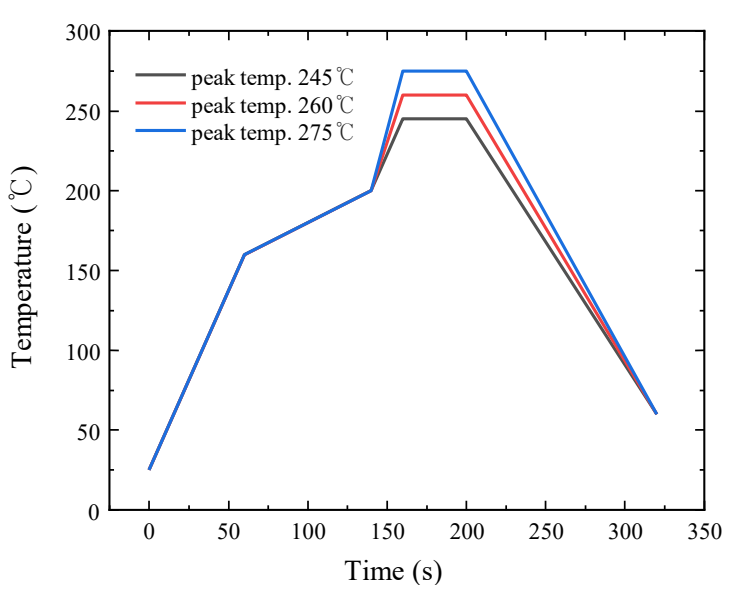

Fig. 3 Temperature profiles used in reflow process

그림에서 보는 바와 같이, 진공 리플로우 공정에서는 진공 분위기 및 개미산 (Formic acid)을 사용하여 공 정이 수행되었으며, 접합 최고 온도는 $250{ }^{\circ} \mathrm{C}$ 였다.

접합 공정이 완료된 시편에 있어서 접합부에 생성된 보 이드 등의 결함을 측정하기 위해서 X-ray 장비 (XSCANH160-OCT, XAVIS, KOREA)를 이용하여 비파괴 (nondestructive) 분석이 수행되었다. 페이스트를 사용한 TLP 접합 공정 후, 시편이 에폭시 소재로 마운팅 (mounting)

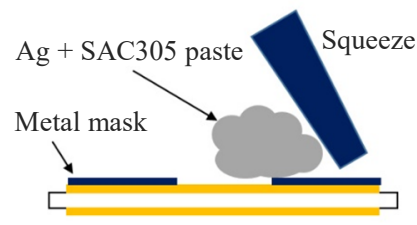

DBC substrate

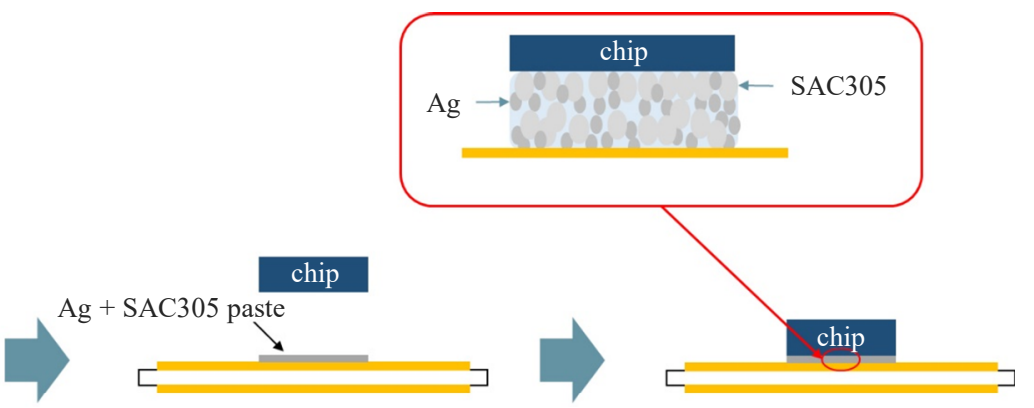

Fig. 2 Schematics of paste printing and chip attachment 


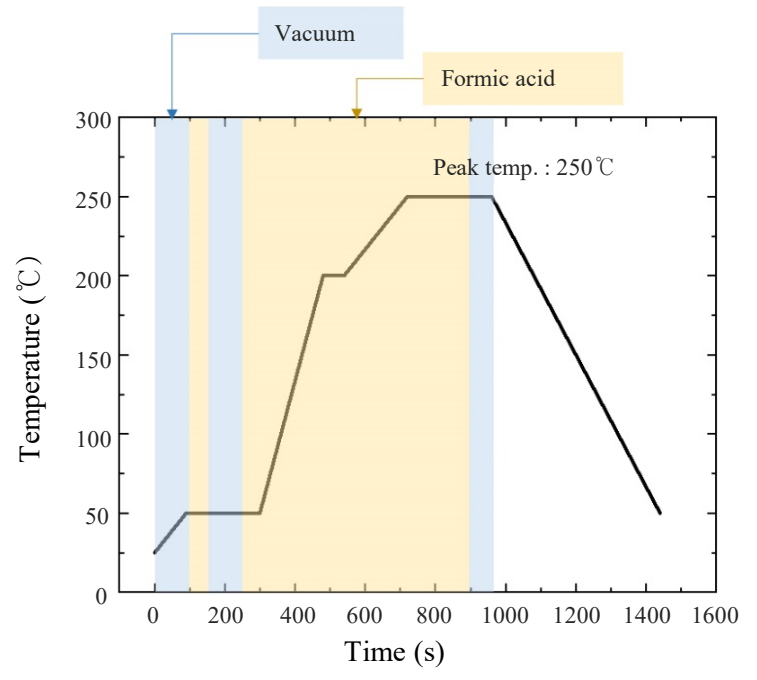

Fig. 4 Temperature profile used in vacuum reflow process

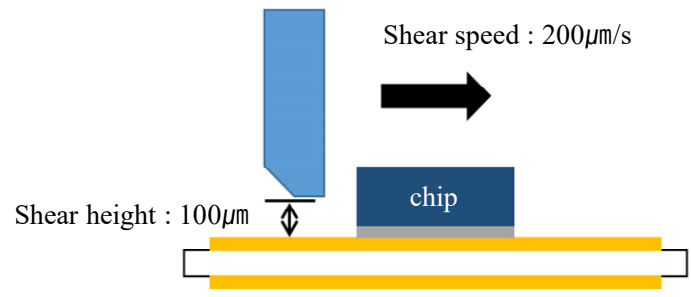

Fig. 5 Schematic of die shear testing

되었으며, 단면의 야금학적인 관찰을 위해 폴리싱 (Polishing) 작업이 수행되었다. 각 시편의 미세구조 및 접합 계면이 $\mathrm{FE}-\mathrm{SEM}$ (field emission scanning electron microscope, INSPECT F, FEI, USA)과 EDX (energy dispersive X-ray spectroscope)를 이용하 여 분석되었다. TLP 접합 시편의 기계적 특성을 평가 하기 위해 칩 전단 시험 (Die shear test)이 전단 시 험장비 (Dage4000, Nordson DAGE, UK)를 사용 하여 수행되었다. 본 실험에서 사용된 전단 시험 조건 으로 전단 속도는 $200 \mu \mathrm{m} / \mathrm{s}$, 전단 높이는 $100 \mu \mathrm{m}$ 가 사용되었다 (Fig. 5). 접합 강도 측정을 위해 총 10개 의 접합 시편에 대한 전단 강도 시험이 수행되었으며, 전단 시험 후 파단면이 분석되었다.

\section{3. 실험 결과}

제조된 $\mathrm{Ag}-\mathrm{Sn} 3.0 \mathrm{Ag} 0.5 \mathrm{Cu}$ 하이브리드 페이스트의 접합 특성을 평가하기 위해 다양한 접합 공정에서 접합 이 수행되었으며, 대표적인 일반 리플로우 및 진공 리 플로우 접합 공정 후 접합 시편의 사진을 Fig. 6에 나 타내었다. 그림에서 보는 바와 같이, 일반 리플로우 공 정으로 수행된 접합 시편의 경우에는 $\mathrm{DBC}$ 구리 금속 (a)

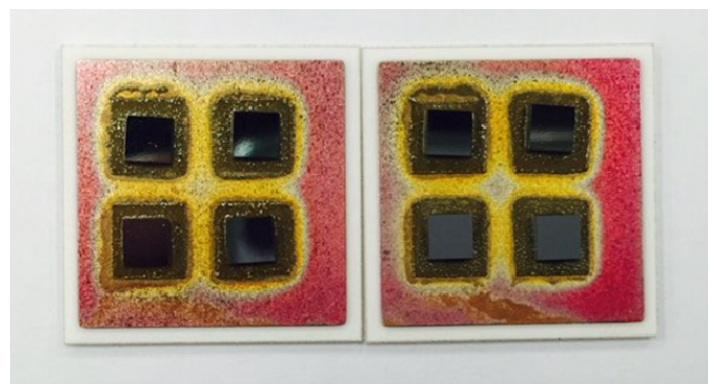

(b)

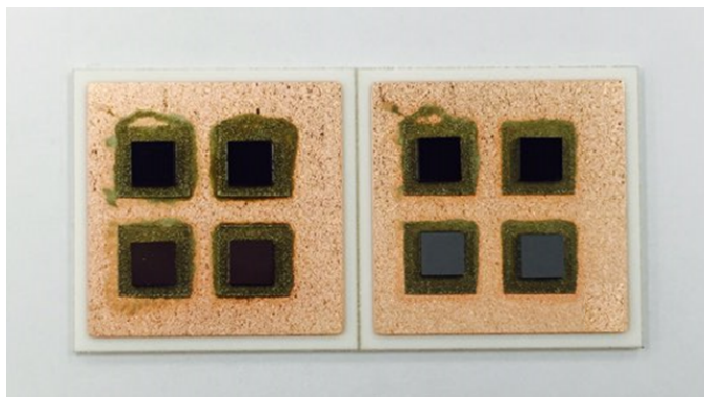

Fig. 6 OM images of (a) air reflowed and (b) vacuum reflowed samples

층의 표면이 산화되어 변색된 것을 확인하였다. 반면, 진공 리플로우 공정으로 수행된 접합 시편의 경우에는 표면 산화가 억제된 것을 확인할 수 있었다. 일반적으로 진공 리플로우 공정 동안에 사용되는 개미산 (Formic acid, $\mathrm{HCOOH}$ )은 끊는점이 약 $101{ }^{\circ} \mathrm{C}$ 이며, 아래 식 과 같이 금속 산화물을 환원시키는 작용을 한다. 아래 에 두 가지 종류의 구리 산화물 $\left(\mathrm{Cu}_{2} \mathrm{O}, \mathrm{CuO}\right)$ 이 개미 산과의 반응으로 환원되는 반응식을 나타내었다.

$$
\begin{aligned}
& \mathrm{Cu}_{2} \mathrm{O}+2 \mathrm{HCOOH} \rightarrow \mathrm{Cu}(\mathrm{COOH})_{2}+\mathrm{Cu}+\mathrm{H}_{2} \mathrm{O} \\
& \mathrm{CuO}+2 \mathrm{HCOOH} \rightarrow \mathrm{Cu}(\mathrm{COOH})_{2}+\mathrm{H}_{2} \mathrm{O} \\
& \mathrm{Cu}(\mathrm{COOH})_{2} \rightarrow \mathrm{Cu}+2 \mathrm{CO}_{2}+\mathrm{H}_{2}
\end{aligned}
$$

Fig. 7은 다양한 접합 조건하에서 접합된 접합부의 비파괴 X-ray 분석 결과 이미지 및 이들 분석된 이미 지를 이미지 소프트웨어 툴을 사용하여 조정된 칼라 이 미지를 보여준다. 그림에서 보는 바와 같이, 접합부 계 면에 계면 박리 (delamination)나 미접합부는 관찰되 지 않았으나, 일반 리플로우 공정에서 접합된 시편의 경우, 접합 온도에 상관없이 상대적으로 많은 보이드가 접합부에 존재함을 확인할 수 있었다. 이와는 대조적으 로, 진공 리플로우 공정에서 접합된 시편의 경우 상대 적으로 큰 결함 없이 양호한 접합부를 형성하였음을 확 인할 수 있었다.

Fig. 8은 $245{ }^{\circ} \mathrm{C}$ peak 온도에서 일반 리플로우 공 정으로 접합된 $\mathrm{Si}$ chip/DBC 접합부 계면 $\mathrm{SEM}$ 사진 을 보인 것으로, 전체 접합부에서 있어서 칩 계면, 접 


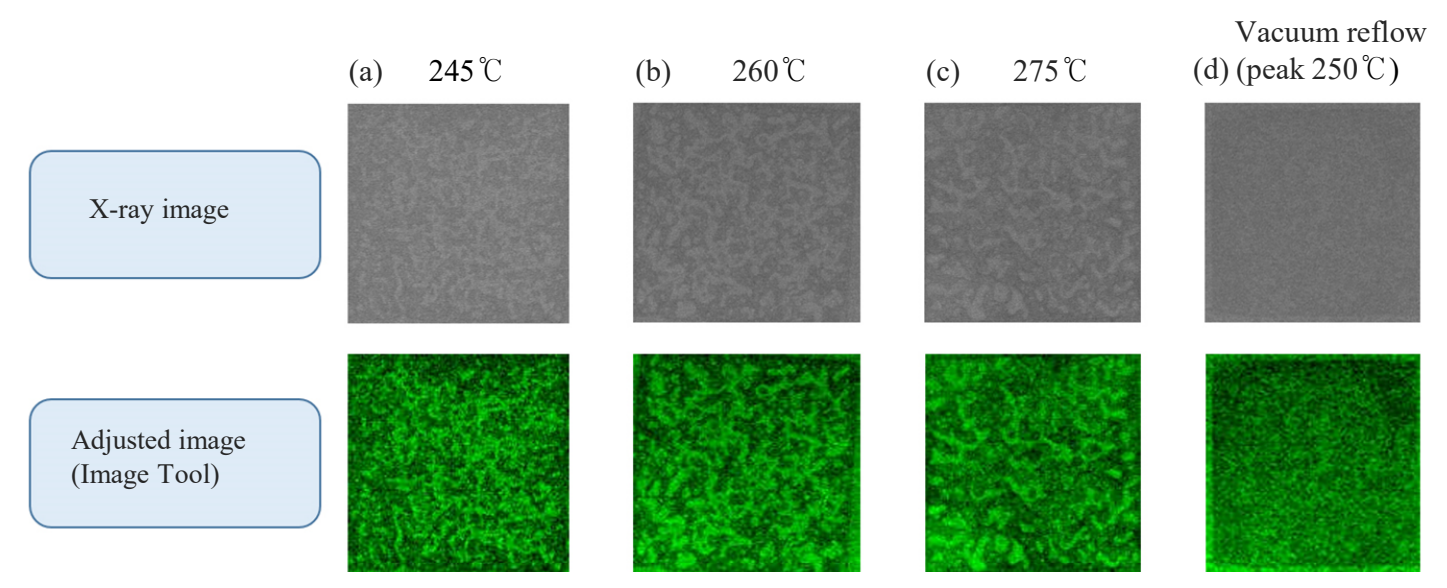

Fig. 7 X-ray images and corresponding adjusted images by image tool software of bonded joints under various conditions

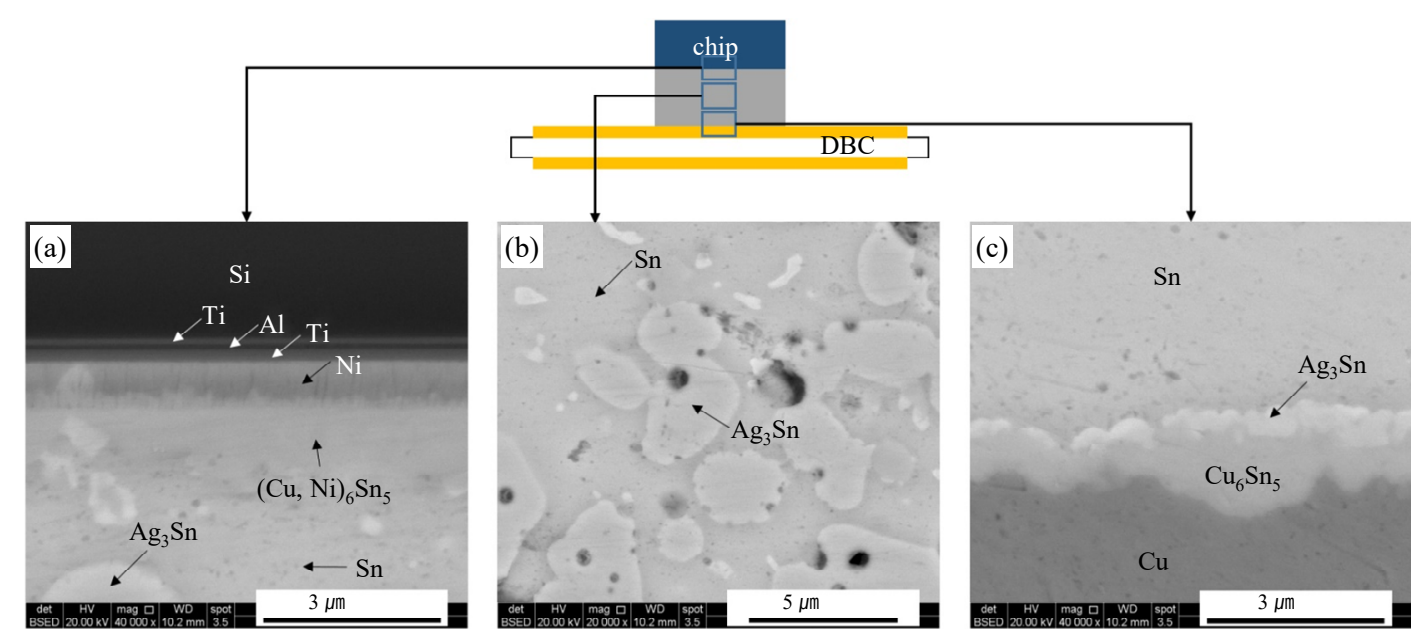

Fig. 8 Cross-sectional SEM images of a Si chip/bonding layer/DBC joint (peak reflow temperature: $245{ }^{\circ} \mathrm{C}$ )

합부 중앙, $\mathrm{DBC}$ 계면 $\mathrm{SEM}$ 사진을 각각 모식도와 함 께 위치별로 나타내었다. 접합 반응 동안, 칩 metallization의 최종 금속 층인 $\mathrm{Ag}$ 는 솔더와의 반응으로 모두 용해되어 솔더 내부에서 화합물 층을 형성하였으 며, 그 다음 금속 층인 $\mathrm{Ni}$ 과의 반응이 일어남을 확인 할 수 있었다. 이러한 반응을 통해 칩 접합부 계면에는 $\mathrm{Ni}$ 이 포함된 $(\mathrm{Cu}, \mathrm{Ni})_{6} \mathrm{Sn}_{5}$ 금속간화합물 층이 형성되 었음을 확인하였다 (Fig. 8(a)). 접합부 중앙 부위를 관찰한 결과, $\mathrm{Sn}-3.0 \mathrm{Ag}-0.5 \mathrm{Cu}$ 솔더 내에 첨가된 $\mathrm{Ag}$ 의 영향으로 인해 $\mathrm{Ag}$ 와 $\mathrm{Sn}$ 의 화합물인 $\mathrm{Ag}_{3} \mathrm{Sn}$ 금속간 화합물이 상당 부분 형성되어 균일하게 분포함을 확인 할 수 있었다 (Fig. 8(b)). 아래 $\mathrm{DBC}$ 기판 계면을 분석한 결과, $\mathrm{DBC}$ 기판의 $\mathrm{Cu}$ 층과 솔더와의 반응으 로 인해 계면에는 $\mathrm{Cu}_{6} \mathrm{Sn}_{5}$ 금속간화합물 층이 형성되 었음을 확인할 수 있었으며, 또한 첨가된 $\mathrm{Ag}$ 로 인해 $\mathrm{Ag}_{3} \mathrm{Sn}$ 금속간화합물이 $\mathrm{Cu}_{6} \mathrm{Sn}_{5}$ 금속간화합물 층 위에 추가로 형성되었음을 확인하였다 (Fig. 8(c)). Fig. 9 와 Fig. 10 은 각각 $260{ }^{\circ} \mathrm{C}$ 와 $275{ }^{\circ} \mathrm{C}$ 의 peak 온도에
서 일반 리플로우 공정으로 접합된 $\mathrm{Si}$ chip/DBC 접 합부 계면 SEM 사진을 보인 것이다. Fig. 8 의 $245{ }^{\circ} \mathrm{C}$ 의 결과와 비교하였을 때, 일부 접합부 계면에 형성된 금속간화합물의 크기 및 두께가 성장한 것이 관찰되었 으나, 전반적으로 큰 차이는 관찰되지 않았다. 본 연구 에서 $15{ }^{\circ} \mathrm{C}$ 차이의 리플로우 peak 온도 변화가 접합 부 미세 조직에 있어서는 크게 영향을 미치지 않는 것 을 확인하였다.

Fig. 11은 진공 리플로우 공정으로 접합된 Si chip/ $\mathrm{DBC}$ 접합부 계면의 위치별 $\mathrm{SEM}$ 사진을 보인 것이다. $\mathrm{EDX}$ 조성 분석 결과, 칩 계면, 접합부 중앙 및 $\mathrm{DBC}$ 계면에서 관찰된 화합물의 종류는 일반 리플로우 공정 을 통해 접합된 시편과 동일한 것으로 확인되었다. 하 지만, 전반적으로 접합부 계면 및 중앙 부위에 각각 조 대한 $\left(\mathrm{Cu}, \mathrm{Ni}_{6}\right)_{6} \mathrm{Sn}_{5}, \mathrm{Ag}_{3} \mathrm{Sn}$ 및 $\mathrm{Cu}_{6} \mathrm{Sn}_{5}$ 금속간화합물 이 형성되었음을 확인할 수 있었다.

일반 리플로우 및 진공 리플로우 공정을 통해 접합된 접합부의 기계적 강도에 미치는 접합 공정 변수의 영향 

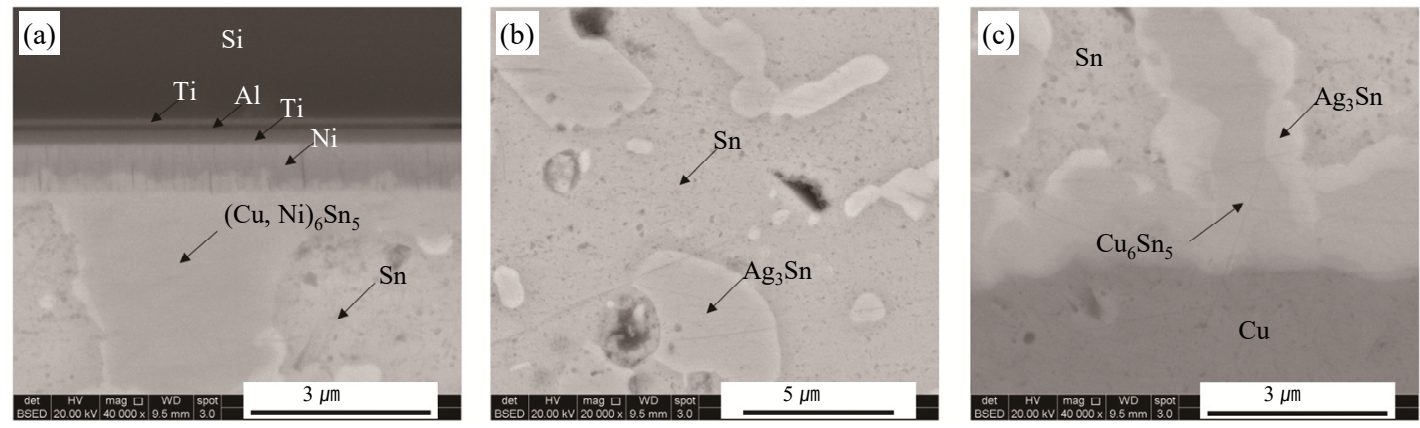

Fig. 9 Cross-sectional SEM images of a Si chip/bonding layer/DBC joint (peak reflow temperature: $260{ }^{\circ} \mathrm{C}$ )
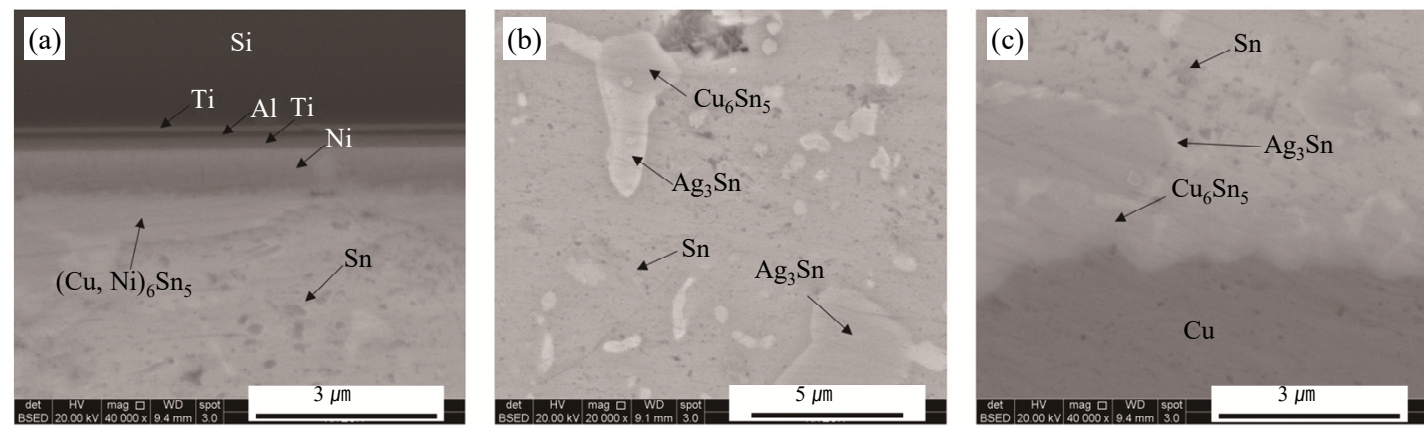

Fig. 10 Cross-sectional SEM images of a Si chip/bonding layer/DBC joint (peak reflow temperature: $275{ }^{\circ} \mathrm{C}$ )
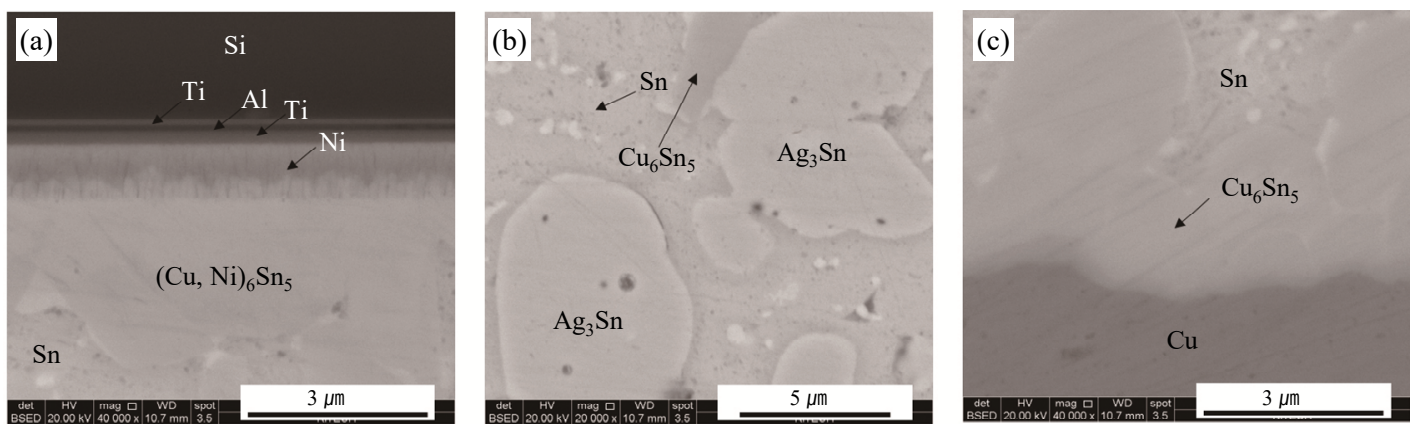

Fig. 11 Cross-sectional SEM images of a Si chip/bonding layer/DBC joint reflowed under a vacuum condition

을 평가하기 위해서 칩 전단 시험이 수행되었으며, 그 결과를 Fig. 12에 나타내었다. 전단 강도 시험 결과에 서 보는 바와 같이, 일반 리플로우 공정으로 접합된 시 편의 경우 peak 온도 변화에 관계없이 약 $20 \mathrm{MPa}$ 내외의 접합 강도를 가짐을 확인하였다. 이와는 대조적 으로 진공 리플로우 공정을 통해 접합된 접합부의 경우 에는 약 $40 \mathrm{MPa}$ 의 평균 강도 값으로 일반 리플로우 공정에 비해 약 2 배 정도 높은 접합부 강도를 가짐을 확인하였다.

칩 전단 강도 차이에 대한 원인을 조사하기 위해 전 단 시험 후 파단면을 관찰하였으며, 그 결과를 Fig. 13 에 나타내었다. 일반 리플로우 공정으로 접합된 시편의 경우 (Fig. 13(a)-(c)), 전단 시험 후 파단이 주로 칩

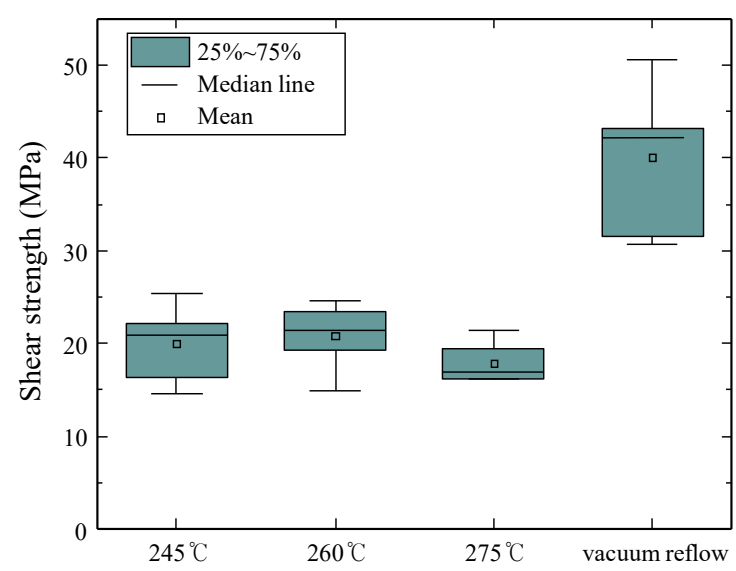

Fig. 12 Variation of die shear strength with reflow conditions 

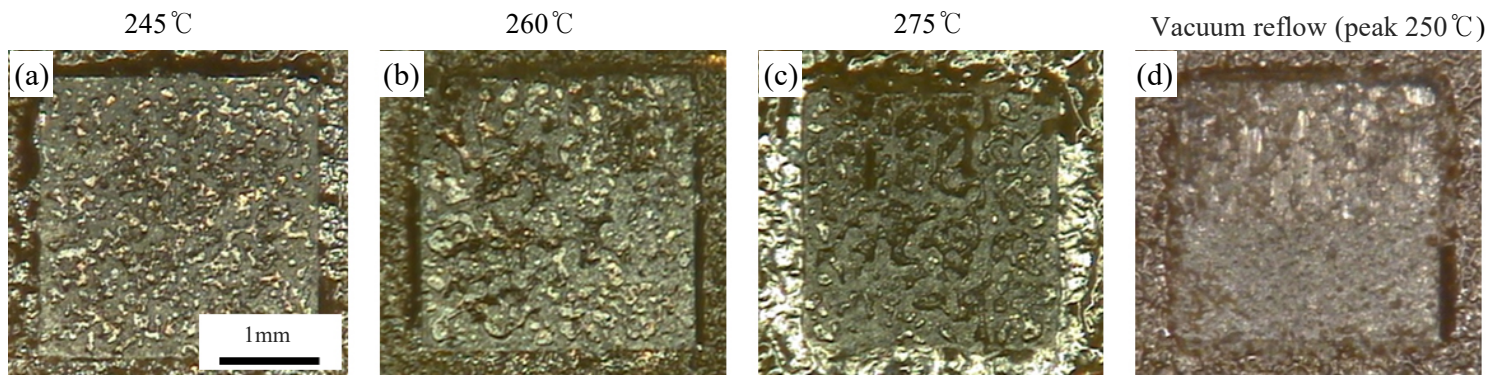

Fig. 13 Fracture surfaces of joints bonded under various conditions
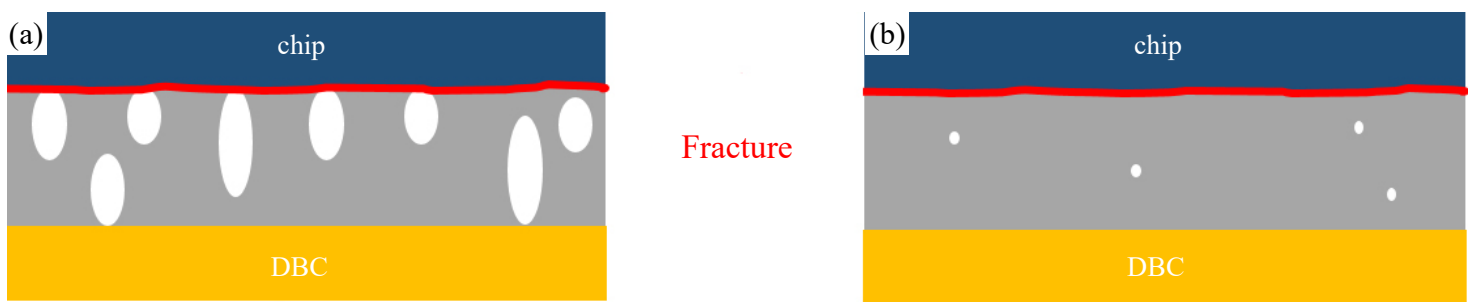

Fig. 14 Schematics of fracture sites after shear testing, (a) air reflow sample and (b) vacuum reflow sample

계면에서 발생하는 것을 확인 할 수 있었으며, 파단면 상에서 다수의 보이드의 존재를 확인할 수 있었다. 반 면, 진공 리플로우 공정을 통해 접합된 접합부의 경우 (Fig. 13(d))에는 전단 시험 후 파단은 역시 칩 계면 에서 발생하는 것을 확인 할 수 있었으나, 파단면 상에 서 보이드의 존재는 크게 확인되지 않았다. 이들 결과 로 미루어 보아, 본 연구에서 사용된 서로 다른 리플로 우 접합 공정 후에 생성된 접합부 보이드의 량 및 크기 가 접합부 강도에 크게 영향을 미치는 것을 확인할 수 있었다. 이러한 접합 강도 차이(Fig. 12)의 결과는 상 기에서 언급한 접합 공정 변화에 따른 접합부 보이드 관찰 결과(Fig. 7)와 일치하는 경향을 보였으며, 이들 결과를 종합하여 정리한 모식도를 Fig. 14에 나타내었 다. 비록, 본 연구에서 사용된 일반 리플로우와 진공 리플로우 공정 온도 및 유지 시간 등의 조건이 정확히 일치하지는 않지만, 일반적으로, 진공 리플로우 공정에 서는 Fig. 4에서 보는 바와 같이, 초기에 진공 및 개 미산의 작용을 2 3차례 교차적으로 수행하므로 써 시 편에 형성된 산화물을 환원시켜 제거하고 또한 진공도 를 향상시키기 위한 작업이 필수적으로 사용된다. 또 한, Peak 온도에서 유지시에도 다시 진공도를 증가시 켜 용융된 솔더 및 접합부에 존재하는 기공을 현격하게 감소시키는 작용을 한다. 이러한 이유로 인해 일반 리 플로우 공정에 비해 진공 리플로우 공정 시간은 다소 긴 시간이 소요되는 특징이 있다. 반면, 일반 리플로우 공정에서는 용융된 솔더 합금이 칩과 기판 금속사이에 서 금속학적인 반응이 일어나는 동안에 접합부 내에 존
재하는 기공의 자연적인 배출은 일반적으로 거의 일어 나지 않는다. 또한, 전력반도체 칩의 사이즈가 일반적 으로 가로 및 세로의 길이가 수 $\mathrm{mm}$ 에서 $10 \mathrm{~mm}$ 내외 길이 정도의 면적을 가지고 있기 때문에, 이들 용융 솔 더 내의 보이드의 자연적인 제거는 더욱 일어나기가 어 렵게 된다. 또한, 진공 리플로우 공정에서 사용되는 개 미산의 작용은 전술한 바와 같이, 시편에 존재하는 산 화물의 환원 작용을 하며, 이러한 개미산의 작용과 진 공 분위기의 조합이 접합부 보이드를 크게 감소시키는 역할로 작용하였다. 선행 문헌 결과에 의하면, $\mathrm{Cu}-\mathrm{Sn}$ $\mathrm{TLP}$ 접합부의 경우 접합부 보이드의 최소화 및 $\mathrm{Cu}_{3} \mathrm{Sn}$ 화합물 생성 반응의 유도에 의해 약 $50 \mathrm{MPa}$ 정도의 높은 접합부 강도를 얻었으며, 전단 시험 결과 칩 계면 을 따라 전단 파괴가 발생함을 보고하였다 ${ }^{9)} . \mathrm{Sn}$ 기반 TLP 접합의 경우, 저비용 고온 대응 접합 소재로서의 장점으로 인해 향후 충분한 신뢰성 검증 후 전기자동차 및 고온 대응 전자 부품과 모듈 등에 활용이 점차 확대 될 것으로 예상된다. 따라서 본 연구에서는 그에 대한 기초 연구로서 고온 대응 접합 소재 적용을 위해 리플 로우 공정 변수에 따른 접합부 야금학적 특성 평가 및 기계적 특성 평가를 수행하였다. $\mathrm{Sn}$ 기반 저융점 금속 소재 및 합금을 이용하여 TLP 접합 공정을 수행할 경 우, 접합부 강도 확보 및 장기 신뢰성을 보장하기 위해 서는 진공 리플로우 공정 적용이 추천되며, 접합부 보 이드의 보다 엄격한 관리가 필요할 것으로 생각된다. 향후, 이와 관련된 보다 세밀한 추가 연구가 필요하리 라 생각된다. 


\section{4. 결 론}

본 연구에서는 고온 환경하에서 동작이 가능한 전력 반도체 모듈에 있어서 TLP 접합의 적용 가능성을 검증 하기 위한 기초 연구로서, 은 $(\mathrm{Ag})$ 과 $\mathrm{Sn}-3.0 \mathrm{Ag}-0.5 \mathrm{Cu}$ 솔더 접합 소재를 이용한 하이브리드 솔더 페이스트 (Hybrid Solder Paste)를 제작한 후, TLP 접합 공 정 변화에 따른 접합부 미세구조의 변화 및 기계적 강 도 평가가 수행되었으며, 다음과 같은 결론이 얻어졌다.

1) 진공 리플로우 공정으로 수행된 접합 시편의 경 우에는 개미산이 금속 산화물을 환원시키는 역할을 하 였으며, 기판의 표면 산화가 크게 억제되었다. 접합부 의 비파괴 X-ray 분석 결과, 일반 리플로우 공정에서 접합된 시편의 경우, 상대적으로 많은 보이드가 접합부 에 존재하였으나, 진공 리플로우 공정에서 접합된 시편 의 경우, 상대적으로 보이드가 없는 양호한 접합부를 형성하였다.

2) 접합부 단면 관찰 결과, 공정 변수에 관계없이 칩 계면, 접합부 중앙 및 $\mathrm{DBC}$ 계면에 각각 $\left(\mathrm{Cu}, \mathrm{Ni}_{6}\right)_{6} \mathrm{Sn}_{5}$, $\mathrm{Ag}_{3} \mathrm{Sn}$ 및 $\mathrm{Cu}_{6} \mathrm{Sn}_{5}$ 금속간화합물들이 형성되었음을 확 인하였다.

3) 전단 시험을 통한 접합부 기계적 강도 측정 결과, 진공 리플로우 공정을 통해 접합된 접합부의 경우에는 약 $40 \mathrm{MPa}$ 의 평균 강도 값을 가졌으며, 일반 리플로 우 공정에 비해 약 2 배 정도 높은 접합부 강도를 가졌 다. 접합 공정 후에 접합부 내부에 생성된 보이드의 량 및 크기가 접합부 강도에 크게 영향을 미치는 것을 확 인하였다.

4) 향후, $\mathrm{Sn}$ 기반 저융점 금속 소재 및 합금을 이용 하여 TLP 접합 공정을 수행할 경우, 접합부 강도 확보 및 장기 신뢰성을 보장하기 위하여 진공 리플로우 분위 기 하에서 접합부 보이드의 엄격한 관리가 필요할 것으 로 생각되며, 이에 대한 보다 체계적인 최적화 연구가 필요할 것으로 생각된다.

\section{감사의 글}

이 논문은 2020년도 충북대학교 학술연구지원사업의 지원과 2021년도 정부(산업통상자원부)의 재원으로 한 국산업기술진흥원(P0008458, 2021년 산업혁신인재성 장지원사업)의 지원을 받아 수행된 연구임.

ORCID: Jeong-Won Yoon: http://orcid.org/0000-0001-8708-542X ORCID: Dong-Hwan Lee: https://orcid.org/0000-0003-1694-0198

\section{References}

1. A. Matallana, E. Ibarra, I. López, J. Andreu, J.I. Garate,
$\mathrm{X}$. Jordà, and J. Rebollo, Power module electronics in $\mathrm{HEV} / \mathrm{EV}$ applications: New trends in wide-bandgap semiconductor technologies and design aspects, Renew. Sust. Energ. Rev. 113 (2019) 109264.

https://doi.org/10.1016/j.rser.2019.109264

2. J. W. Yoon, J. H. Bang, Y. H. Ko, S. Yoo, J. K. Kim, and C. W. Lee, Power module packaging technology with extended reliability for electric vehicle applications, $J$. Microelectron. Packag. Soc. 21 (4) (2014) 1-13. http://dx.doi.org/10.6117/kmeps.2014.21.4.001

3. F. Dugal and M. Ciappa, Study of thermal cycling and temperature aging on $\mathrm{PbSnAg}$ die attach solder joints for high power modules, Microelectron. Reliab. 54 (2014) 1856-1861.

http://dx.doi.org/10.1016/j.microrel.2014.08.001

4. B. S. Lee, Y. H. Ko, J. H. Bang, C. W. Lee, S. Yoo, J. K. Kim, and J. W. Yoon, Interfacial reactions and mechanical strength of Sn-3.0Ag-0.5Cu/Ni/Cu and $\mathrm{Au}-20 \mathrm{Sn} / \mathrm{Ni} / \mathrm{Cu}$ solder joints for power electronics applications, Microelectron. Reliab. 71 (2017) 119-125.

https://doi.org/10.1016/j.microrel.2017.03.011

5. J. Son, M. Kim, D. Y. Yu, Y. H. Ko, J. W. Yoon, C. W. Lee, Y. B. Park, and J. Bang, Thermal aging characteristics of $\mathrm{Sn}-\mathrm{xSb}$ solder for automotive power module, $J$. Weld. Join. 35 (5) (2017) 38-47. https://doi.org/10.5781/JWJ.2017.35.5.6

6. B. S. Lee, J. H. Back, and J. W. Yoon, Effect of sintering conditions on microstructure and mechanical strength of $\mathrm{Cu}$ micro-particle sintered joints for high-power semiconductor module applications, J. Weld. Join. 37 (2) (2019) 26-34. https://doi.org/10.5781/JWJ.2019.37.2.5

7. Y. H. Byun, C. M. Jeong, J. W. Yoon, C. H. Kim, C. S. Kim, B. W. Lee, S. W. Booh, and U. I. Chung, A novel and simple fabrication technology for high power module with enhanced thermal performance, Proc. 8th IEEE Vehicle Power and Propulsion Conference (VPPC) (2012) 1070-1073. https://doi.org/10.1109/VPPC.2012.6422503

8. J. F. Li, P. A. Agyakwa, and C. M. Johnson, Interfacial reaction in $\mathrm{Cu} / \mathrm{Sn} / \mathrm{Cu}$ system during the transient liquid phase soldering process, Acta Mater. 59 (2011) 1198-1211. https://doi.org/10.1016/j.actamat.2010.10.053

9. B. S. Lee and J. W. Yoon, Cu-Sn intermetallic compound joints for high-temperature power electronics applications, J. Electron. Mater. 47 (2018) 430-435. https://doi.org/10.1007/s11664-017-5792-2

10. J. W. Yoon and S. E. Jeong, Transient liquid phase sinter bonding with Tin-Nickel micro-sized powders for EV power module applications, J. Microelectron. Packag. Soc. 28 (2) (2021) 71-79. https://doi.org/10.6117/kmeps.2021.28.2.071

11. B. S. Lee and J. W. Yoon, Die-attach for power devices using the Ag sintering process: Interfacial microstructure and mechanical strength, Met. Mater. Int. 23 (2017) 958-963.

https://doi.org/10.1007/s12540-017-6908-1 
12. J. W. Yoon and J. H. Back, Effect of sintering conditions on the mechanical strength of $\mathrm{Cu}$-sintered joints for high-power applications, Materials. 11 (2018) 2105. https://doi.org/10.3390/ma11112105

13. K. S. Siow, Mechanical properties of nano-silver joints as die attach materials, J. Alloys Compd. 514 (2012) 6-19. https://doi.org/10.1016/j.jallcom.2011.10.092

14. J. W. Yoon, S. Bae, B. S. Lee, and S. B. Jung, Bonding of power device to ceramic substrate using Sn-coated $\mathrm{Cu}$ micro paste for high-temperature applications, Appl. Surf. Sci. 515 (2020) 146060. https://doi.org/10.1016/j.apsusc.2020.146060

15. J. Liu, K. Wang, F. Yu, C. Hang, X. Fu, H. Chen, and M. Li, A paste based on $\mathrm{Cu} @ \mathrm{Sn} @$ Ag particles for die attachment under ambient atmosphere in power device packaging, J. Mater. Sci. Mater. Electron. 31 (2020) 1808-1816.

https://doi.org/10.1007/s10854-019-02697-9
16. L. Sun, Y. Zhang, L. Zhang, and C.P. Chen, Reliability and strength of $\mathrm{Cu}-\mathrm{Sn} 0.5 \mathrm{CuZnAl}-\mathrm{Cu}$ TLP bonded joints during thermal cycling, J. Mater. Sci. Mater. Electron. 32 (2021) 19264-19274. https://doi.org/10.1007/s10854-021-06446-9

17. S. E. Jeong, S. B. Jung, and J. W. Yoon, Fast formation of Ni-Sn intermetallic joints using Ni-Sn paste for high-temperature bonding applications, J. Mater. Sci. Mater. Electron. 31 (2020) 15048. https://doi.org/10.1007/s10854-020-04068-1

18. M. Fujino, H. Narusawa, Y. Kuramochi, E. Higurashi, and T. Suga, Transient liquid-phase sintering using silver and tin powder mixture for die bonding, Japan $J$. Appl. Phys. 55 (2016) 04EC14. https://doi.org/10.7567/JJAP.55.04EC14 